\title{
Characteristics of Cottage Industries in Kakamega County, Kenya
}

\author{
PaulPeter M. Makokha \\ P. O Box 51175-00100 GPO \\ Nairobi, KENYA. \\ Email: paulpetermakokha@yahoo.com
}

Doi:10.5296/ijhrs.v4i4.6621 URL: http://dx.doi.org/10.5296/ijhrs.v4i4.6621

\begin{abstract}
Cottage industries are the home-based units of production which rely on human- or animal-propelled skills and technology. They are characterized by accessibility to raw materials, low costs of operation, and proximity to markets. The cottage industries highlighted in this research paper are: pottery, crude sugar production, brick-making, liquor production, quarrying and masonry, carpentry, traditional medicine production, charcoal production, basketry and weaving, baking, bicycle repair, flour-grinding, and shoe-making and repair.
\end{abstract}

Key Words: Characteristics, Cottage Industries, Kakamega

\subsection{Introduction}

Rao and Saha (1986) define a cottage or household industry as one in which production is undertaken at the residential localities, products are made by the members of the family, and the products are sold in the markets. The capital requirement is very small, and hence, it is usually supplied by the master of the house. The examples of cottage industries they cite are: handloom, jewellery, basketry, toy making, pottery, carpentry, wood or ivory carving. They observe that these industries are either on full-time or part-time basis, and rely on traditional skills or simple technologies. Puri (1988) is of the opinion that cottage industries provide the greatest opportunity for making every home a factory.

The Kakamega District Development Plan (1997-2001) cites wood carving, bakeries, soap production, boat-making, the production of bricks and roofing tiles, bicycle repairs, et cetera, as some of the cottage industries in the district. Staley and Morse (1965) point out that sometimes crafts are practiced specifically by certain tribes, and give the example of Senegal, where some villages are exclusively inhabited by blacksmiths. They further observe that there are instances where different crafts are practiced within the same family, for example in Sudan, the wife of a blacksmith is traditionally engaged in pottery making or, more rarely, in textile dyeing, whereas in Guinea, weavers also work as carpenters or potters.

Rao and Saha (1986) note that cottage industries have a greater presence in rural than in urban areas; this helps check rural-urban influx by providing jobs to the rural unemployed and reduce their chances of migrating to the urban centers. Kaplan (2009) points out that 
cottage industries use less capital and simple technology which enables them to be capable of quick production. As a result, they are complimentary to large-scale industries; they offer raw materials or semi-finished goods to the large industries.

Staley and Morse (1965) observe that some activities of cottage industries were highly seasonal in most of the industries, and a good majority of the owners pursued subsidiary avocations mainly as farmers or agricultural laborers.

\subsection{METHODOLOGY}

This research paper employed the exploratory research design (field studies). This design was preferred because the study was basically a fact-finding mission; to find out the characteristics of cottage industries in Kakamega County, Kenya. The research was both qualitative and quantitative in nature.

\subsection{Areas of Study}

Kakamega County is a part of the larger Western Province of Kenya. It is predominantly inhabited by the Luhya-speaking community. This study was conducted in three districts in the county, namely: Kakamega North, Kakamega East, and Lugari.

Kakamega North District is situated off the Eldoret-Webuye Road, on the way to Kakamega Town. It is 427.4 square kilometres in size, has a population density of 480 persons per square kilometre, and 40,635 households with an approximate population size of 205,166 people. This district has four divisions, namely: Kabras Central, Kabras South, Kabras, East, Kabras North, and Kabras West (Kenya National Bureau of Statistics, 2009).

Kakamega East District is located along the Kakamega-Kisumu Highway. It is 445.5 square kilometres in size, has a population density of 358 persons per square kilometre, and 34,177 households with an approximate population size of 159,475 people. This district has three divisions, namely: Shinyalu, Ileho, and Kakamega Forest.

Lugari District is situated along the Eldoret-Webuye Road. It is 668.9 square kilometres in size, has a population density of 437 persons per square kilometre, and 59,476 households with an approximate population size of 292,151 people.

This district has three divisions, namely: Matete, Lugari, and Likuyani. Kakamega North, Kakamega East, and Lugari Districts have their provincial headquarters in Kakamega Town, also the county headquarters. However, due to the constraints of time and finances, the study was confined to Manda (Sirungai Location, Kabras North Division), Mukhonje (Ilesi Location, Shinyalu Division) and Kivaywa (Chevaywa Location, Matete Division). They receive fairly high levels of rainfall throughout the year, and agriculture is the dominant economic activity. A map of Kakamega is shown in Figure 1. 


\section{$\triangle$ Macrothink}

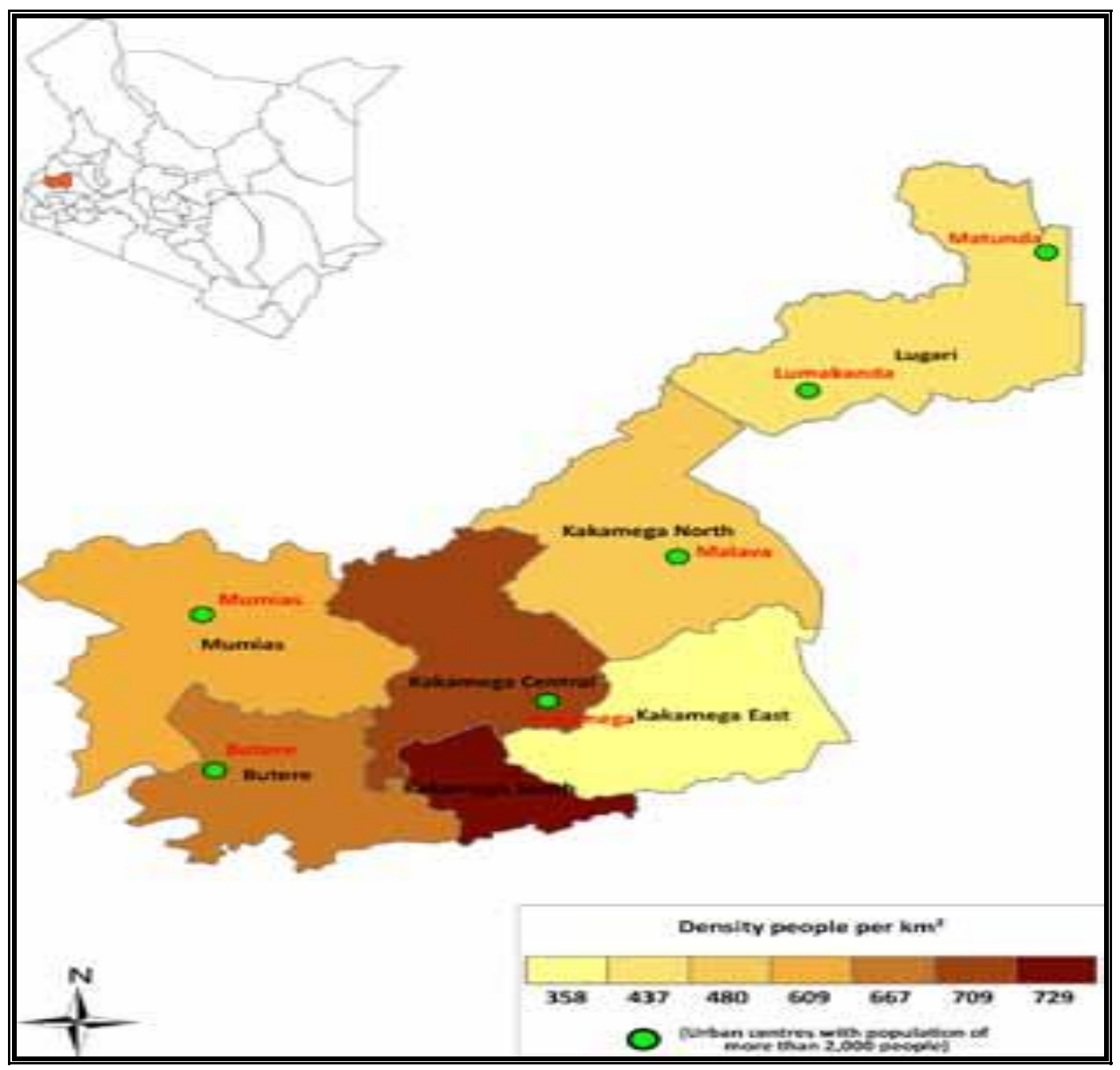

Figure 1: A Map of Kakamega, Kenya.

\subsection{Unit of Analysis and Unit of Observation}

The unit of analysis was the owners and workers in cottage industries while the unit of observation was the cottage industries in the areas of study.

\subsection{Sampling Design and Procedures}

Manda, Mukhonje, and Kivaywa Sub-Locations were purposively selected for the research study. This was after a reconnaissance trip to the areas of study exposed the types of cottage industries the researcher had a keen interest in. The information obtained from the local leaders of Manda, Mukhonje and Kivaywa revealed that these sub-locations had 180, 200 and 170 cottage industries, respectively (a total of 550). According to Krejcie and Morgan (1970), from a population size of 550, a sample size of 226 is to be used. The Proportionate Random Sampling procedure was applied to come up with a sample size of 70, 82, and 74 respondents in Manda, Mukhonje and Kivaywa, respectively, who were picked out through Simple Random Sampling.

\section{$2.4 \quad$ Sources of Data}

\subsubsection{Primary Data}

The sources of primary data included youth, men, and women owning or working in the 
cottage industries, local leaders and key informants in the region.

\subsubsection{Secondary Data}

These included information from publications at the district and national level, for instance, district development plans, national census reports, et cetera.

\subsection{Methods of Data Collection}

\subsubsection{Observation}

In the course of the study, snapshots of the various forms of cottage industries were taken, including those of respondents in their natural setting. An observation check-list was used.

\subsubsection{Focus Group Discussions}

A well-selected group composed of 8-12 members was assembled in each of the three sub-locations, and questions and discussion points were put forth to generate a discussion. Open-ended questions and Focus group Discussion guides were used.

\subsubsection{Semi-scheduled Questionnaire}

A set of research questions was presented to the respondents with the aim of extracting relevant information.

\subsection{Data Analysis}

The data collected was both qualitative and quantitative in nature. This study, therefore, employed descriptive statistics and inferential statistics in the analysis of data.

\section{$2.6 \quad$ Challenges in the Field}

2.6.1 State of roads. The rural road network was quite poor, with impassable roads. The researcher and his assistants had a difficult time skipping and, in some cases, stepping into mud.

2.6.2 Unpredictable weather. Whenever it rained while the researcher was in the remote areas, he always had no otherwise, but to cut short the exercise. At other times, it was simply too hot!

2.6.3 Distance. The research study was tedious. This is because it entailed walking from village to village, using footpaths that motorbikes could not use, and crossing makeshift bridges.

2.6.4 Constraints of time and finances. The study used up a lot of time and finances. However, through sampling, the researcher was still able to obtain relevant information.

\subsection{RESULTS AND DISCUSSION}

\subsection{Demographic Characteristics of Respondents}

The demographic characteristics in this study are: gender, age, sub-location, education level, marital status, and number of children.

\subsubsection{Gender}

This section looks into the composition of the respondents based on their gender. The distribution of males and females based on gender is summarized in Figure 2.

Figure 2: The Gender of Respondents 


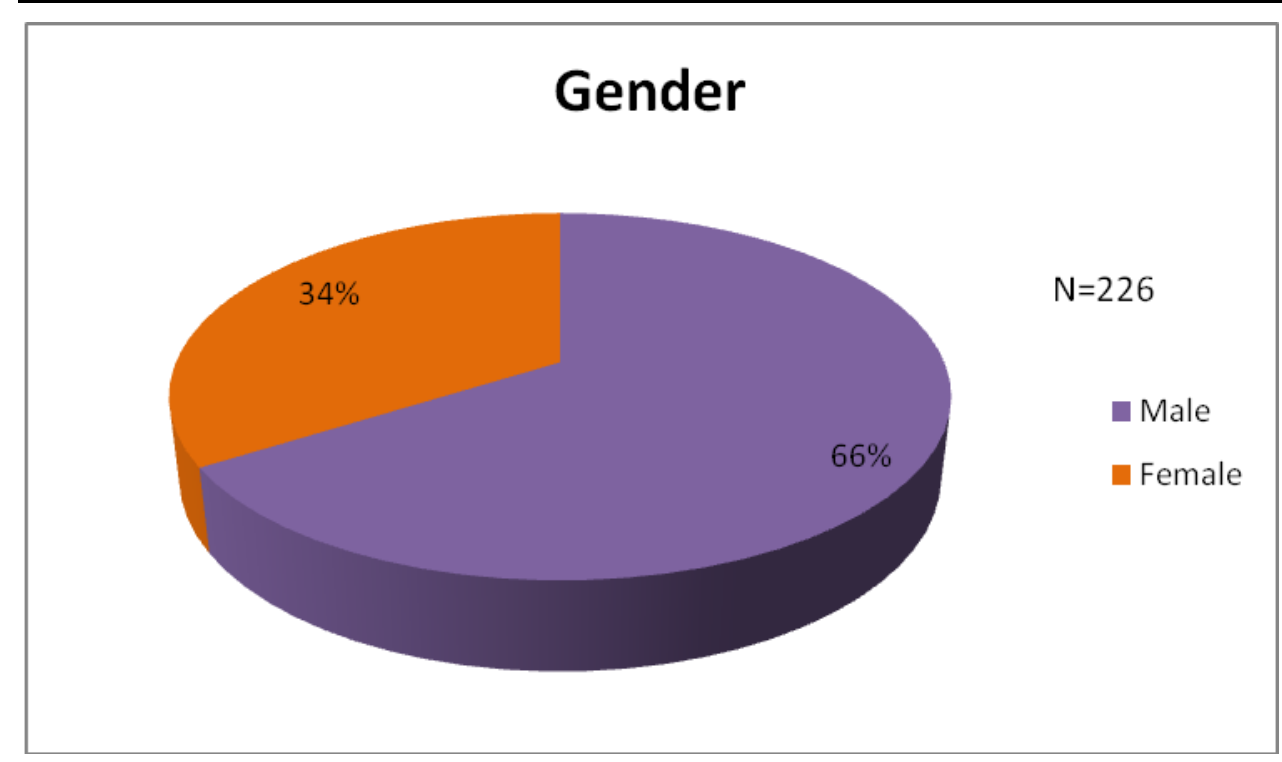

Data in Figure 2 shows that majority of the respondents (66\%) were males while minority (34\%) were females. This could be due to the fact that most of the activities in cottage industries require a lot of stamina. Another reason could be that most women in the countryside spend a significant amount of time carrying out household chores which consume much of the time they would have otherwise spent working in the industries. Blackden and Wodon (2006) observed that since women can only engage in directly productive economic activity after or in conjunction with the discharge of their domestic roles. According to the Kenya Population and Housing Census Report (2009), the rural population percentage of males in Western Province was 48 percent while that of females was 52 percent; this contrasts with the picture on the ground.

\subsubsection{Age}

This section focuses on the ages of respondents, and was categorized into; 17 years and below, 18-50 years, and 51 years and above, according to Ericson's Model (Boeree, 1997). Classification based on age is summarized in Table 3.

Figure 3: The Age Brackets of Respondents 


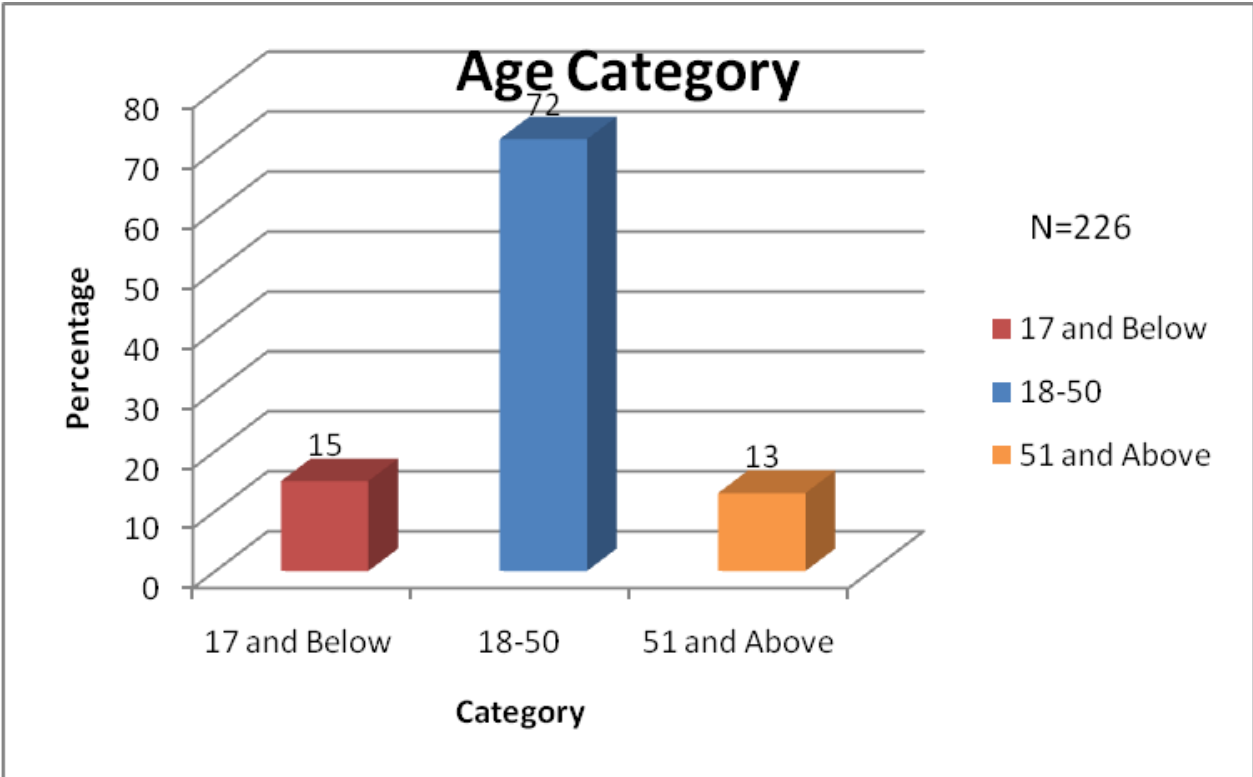

Data in Figure 3 shows that majority of the respondents (72\%) who owned or were employed in cottage industries fell in the 18-50 age brackets. Mosaddeque et al (2008), while looking into farmers' characteristics associated with the participation in cottage industry activities in Bangladesh, observed that the age of most farmers ranged from 18-50 years. This mirrors the findings in this study whereby majority of the owners and workers in cottage industries were in the 18-50 age brackets. The perception among most respondents as regards the high percentage of those in the 18-50 age brackets was that they were the most energetic.

\subsubsection{Level of Education}

This section looks into the education levels of the respondents, which were classified into; no schooling, primary schooling, secondary schooling, and post-secondary schooling. This is presented in Table 1.

Table 1: The Education Level of Respondents

\begin{tabular}{|l|l|l|}
\hline Level of Education & Frequency & Percentage \\
\hline No Schooling & 93 & 41 \\
\hline Primary Schooling & 105 & 47 \\
\hline Secondary Schooling & 22 & 10 \\
\hline Post-secondary Schooling & 5 & 2 \\
\hline Total & 145 & 100 \\
\hline
\end{tabular}

Data in Table 1 shows that those with primary school education were in the majority (47\%) while those with post-secondary education were in the minority (2\%). According to the Kenya Population and Housing Census Report (2009), the percentage of those in Western Province who had primary school education was 61 percent while those with post-secondary education were 3 percent. Both in this study, and in the Census Report, it is evident that the percent of those with post-secondary education was quite low.

It is worth noting that the percentage of those with no schooling was fairly high (41\%). This could be a pointer to high illiteracy levels in the areas of study. The Sub-Chief of Manda 
Sub-Location reinforced this by saying: "Most of the people engaging in cottage industries in this region have fewer options in terms of the type of employment to engage in because they did not go far academically".

The perception among most respondents was that the majority of people in the areas of study engaged in cottage industries due to low levels of education, and they could not secure white-collar jobs. This reflects findings in The Human Development Report (UNDP, 1995) which concluded that the increasingly competitive labour market demands ever-higher levels of education, and that people without it are at a growing disadvantage.

\subsubsection{Marital Status}

This section highlights the marital status of the respondents, which were categorized into: the single, married, divorced, and the widowed. The marital status is summarized in Figure 4.

Figure 4: The Marital Status of Respondents

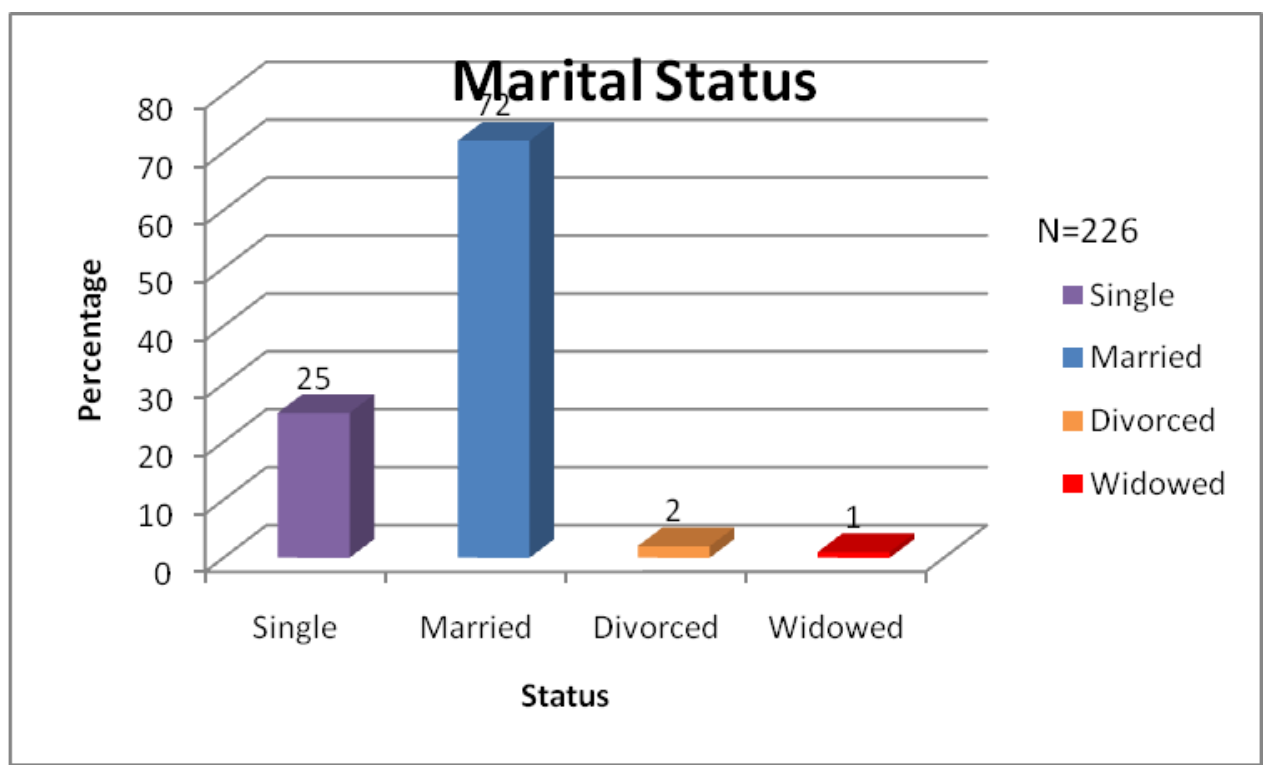

Data in Figure 4 shows that most of the respondents (72\%) were married. The perception among most respondents was that married people engaged in the activities of cottage industries more than the unmarried due to the fact that the married were under pressure to meet the needs of their families. A village elder said: "Most of the owners and workers in these industries are married. They have families to take care of, and therefore, they must find ways to earn a living, hence, their involvement in cottage industries".

Faridi et al (2009), while examining the impact of marital status on female labour force participation, concluded that those who were married were more likely to participate in productive economic activities than those who were not. This reinforces the perception among most of the respondents in the areas of study.

\subsubsection{Number of Children}

This section highlights the number of children per respondent, and was categorized into: no child, one to three children, and more than three children. This is presented in Figure 5.

Figure 5: The Number of Children per Respondent 


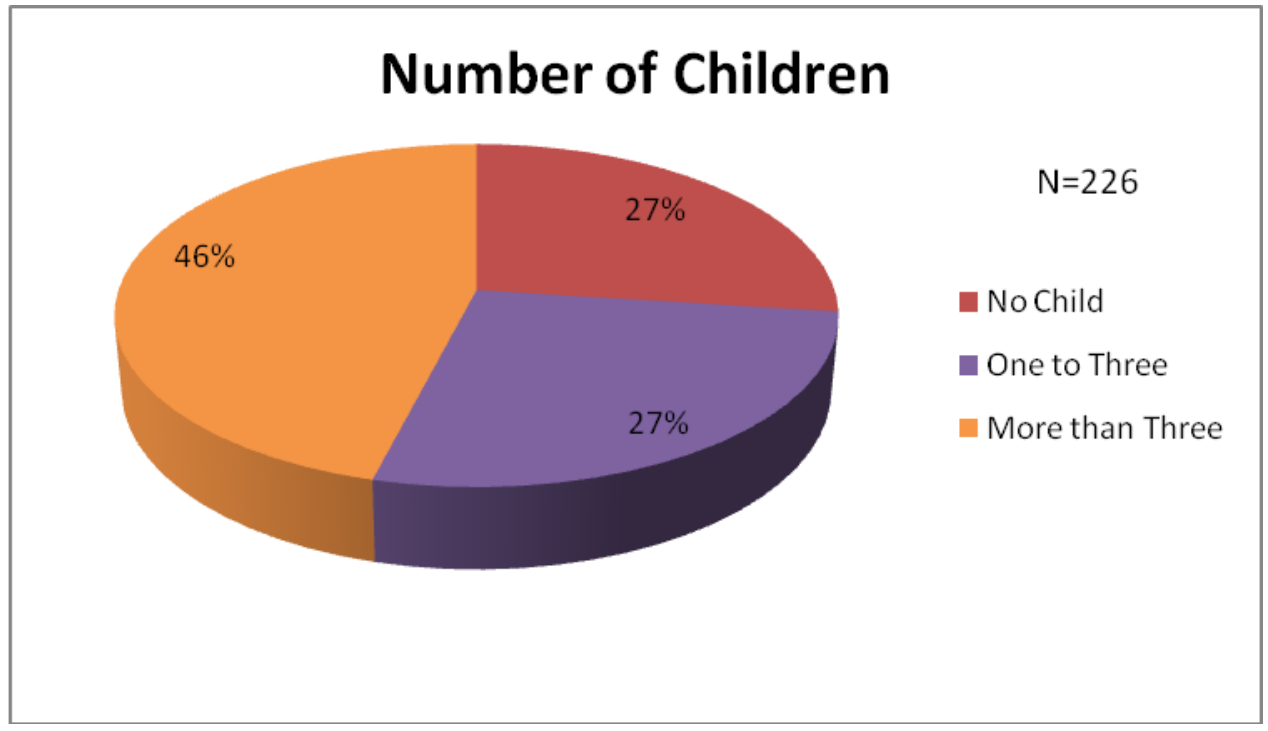

Data in Figure 5 shows that most of the respondents $(46 \%)$ had more than three children while those with none were the least (27\%). It is noteworthy that the percentage of those with more than three children was fairly high! This could be a pointer to the high population growth rate in the areas of study. A village elder said: "People in this area have many children; the higher the number of children, the harder they have to work to meet their family needs".

Faridi et al (2009) observed that the household size significantly and positively influenced the decision of households to engage in home-based work. His findings revealed that the more the dependents, and the larger the number of children, the more the financial burden and economic pressure on a family.

\subsection{The Characteristics of Cottage Industries in Kakamega County, Kenya}

\subsubsection{Pottery}

Data collected through questionnaires indicated that 22 percent of the total number of respondents (226) in this study engaged in pottery. The percentage of cottage industries in Mukhonje which were dealing in clay items was 65 percent. The high involvement in pottery in Mukhonje could be due to the abundant availability of clay, which was readily available along river banks in the area. The Sub-Chief of Mukhonje Sub-Location said: "Most people in this area are potters due to the abundant availability of clay along our river banks".

Pottery as a cottage industry was either self-owned, family-owned, or owned through partnership. One either worked for pay or simply helped out his/her neighbor, friend, or relative. Work for no pay was mostly in cases where by the worker was a member of the family, close friend, or a neighbor who owned a pottery-based cottage industry. On the uses of pots, a village elder said: "Pots are used for preparing liquor, cooking, as traditional fridges for storing and for cooling drinking water, and are also given out as presents in weddings. Almost every household in Luhya-land, no matter the level of poverty in it, at least owns a pot or two; even the rich here buy pots, but mostly for their aesthetic value". 
A single potter could mould at least three big pots in a day. The pots were made with the use of an improvised potter's wheel (tire rims). They are dried under a shade for almost a week, arranged in a kiln and roasted by fire for at least three days, after which the kiln is dismantled and the clay items retrieved. Finished products are ready for sale. In some instances, the potters transported their clay items to nearby markets by themselves, but in most cases, middlepersons bought the products and went to re-sell them in distant markets. The money obtained from the sale of clay items enabled the owners and workers in the pottery-based cottage industries to meet their day-to-day needs.

Potters did not have a problem with the acquisition of clay; the major challenge was its transportation due to the long distance between the working site and the river banks. However, to counter this challenge, they bought lumps of clay from those whose sole work was transporting and selling it. Examples of clay products include: pots, flower jars, jikos, moneybanks, et cetera. Nelson (2013) conducted a similar study which looked into the social, cultural, and economic setting for the production, distribution, and consumption of traditional pottery among the Kamba people of South Eastern Kenya. See Plate 1:

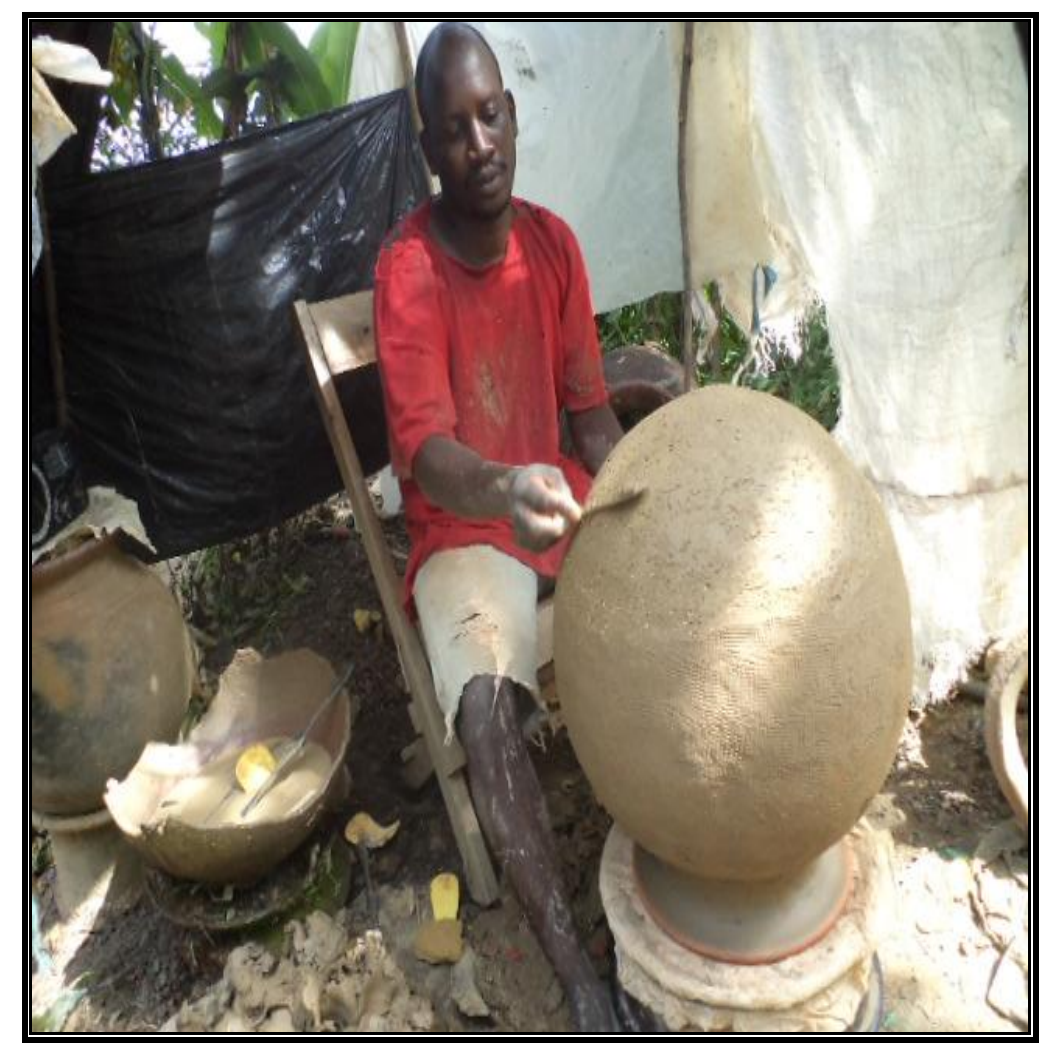

Plate 1: A picture taken in Mukhonje Sub-Location in December 2012 by the researcher, showing a potter giving his clay item the final potter's touches.

\subsubsection{Crude Sugar Production}

Data collected through questionnaires showed that 8 percent of the total number of 


\section{Macrothink}

respondents (226) in this study engaged in crude sugar production. The percentage of those who engaged in crude sugar production in Manda and Kivaywa was 5 percent and 19 percent respectively. Participants in Focus Group Discussions and Key Informant Interviews had cited crude sugar production as one of the cottage industries in Manda and Kivaywa. Sugarcane, being a major cash crop in Western Province, is the raw material used in crude sugar production. A village elder said: "Crude sugar production began due to the need to produce a sweetener for traditional brews and beverages like tea and coffee".

Jaggeries were either self-owned, family-owned, or owned through partnership. Members of the family mostly worked for no pay while outsiders worked for pay. Work for no pay was in cases whereby the worker was a member of the family, close friend, or neighbor who owned a jaggery. These industries had at least three workers because of the workload involved. On average, one hundred and fifty "stones" of crude sugar would be produced in a day. The cane from which sucrose has been extracted would be dried up in the sun and used as firewood or decomposed into manure. Frank (1965) looked into crude sugar production. See Plate 2:

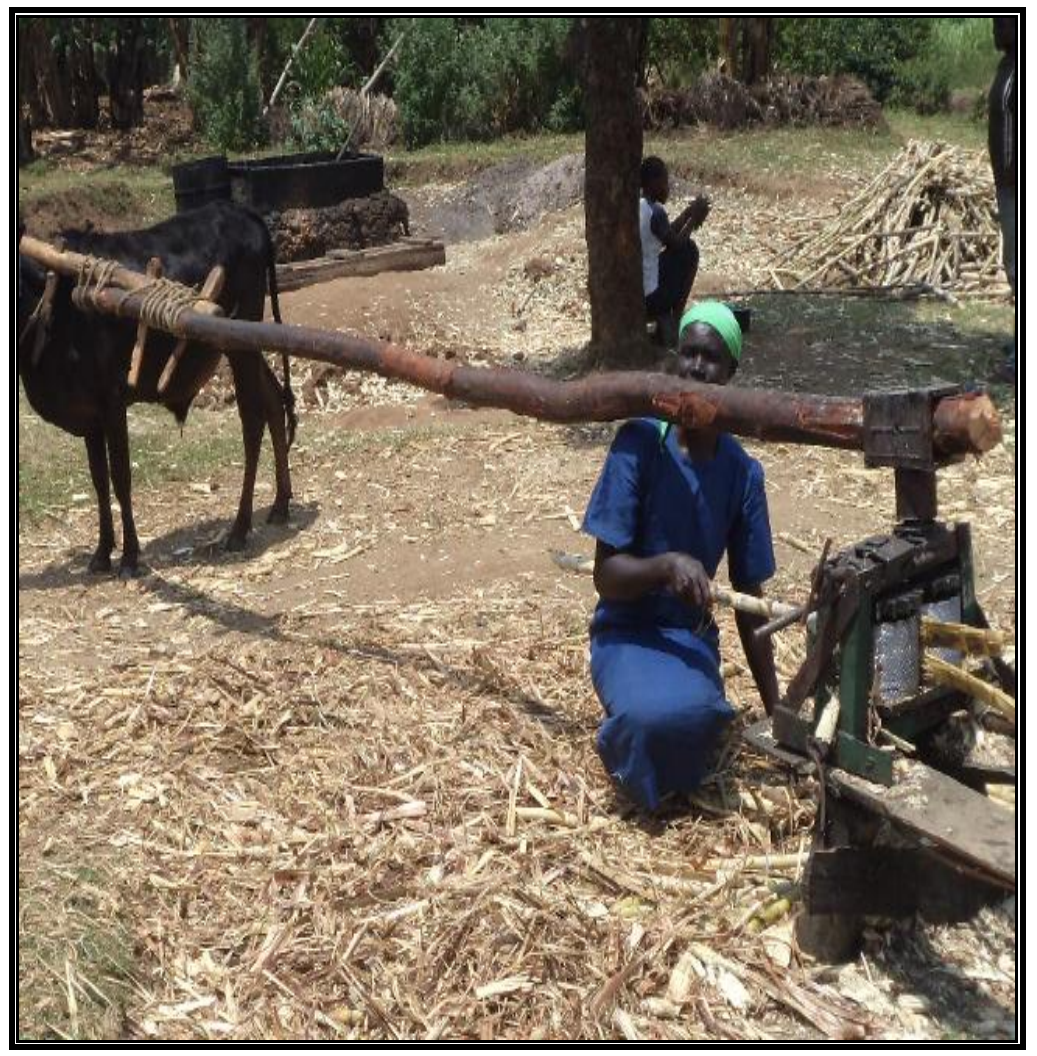

Plate 2: A picture taken in Manda in December 2012, by the researcher, of a woman feeding sugarcane into her oxen-driven crushing machine.

The crude sugar producers could either sell the products by themselves or have middlemen and women go to their homes to buy and re-sell the products elsewhere. Molasses, which is one of the waste products, is used in animal feeds as an appetizer and by liquor producers as a sweetener. Crude sugar is used in making biscuits and sweets. The proceeds obtained by owners and workers in jaggerry-based cottage industries enabled them to earn a living. The major challenge in crude sugar production was scarcity of sugarcane. 


\section{Macrothink}

\subsubsection{Brick-making}

Data collected through questionnaires indicated that 16 percent of the total number of respondents (226) in this study took part in brick-making. The percentage of those who engaged in brick-making in Manda, Mukhonje and Kivaywa was 24 percent, 3 percent, and 23 percent respectively. Participants in the Focus Group Discussions and Key Informant Interviews had cited brick-making as one of the cottage industries in the area. Soil is the major raw material.

Brick-making cottage industries were either self-owned, family-owned, or owned through partnership. One either worked for pay or for no pay. Work for no pay was in instances whereby the worker was a member of the family, close friend, or neighbor who owned a brick-making cottage industry. The typical African traditional houses were mud-walled and grass-thatched. The Sub-Chief of Kivaywa Sub-Location said: "Brick-making was common among British colonial settlers, who constructed brick-walled houses. With time, the Africans who had experience in brick-making also began constructing brick-walled houses. The emergence of modern facilities like schools, churches and hospitals has increased the need for brick-making”.

Soil is mixed with water, covered with polythene, and left to ferment for at least a week. Raw bricks are made from the soil, dried under a shed, arranged in a kiln, and roasted with fire for at least four days. The bricks are then retrieved from the kiln, after which are ready for use or sale. Bricks are used for construction purposes. Muchilwa (2013) conducted a similar study on brick-making, but focused more on the clay brick firing process. See Plate 3: 


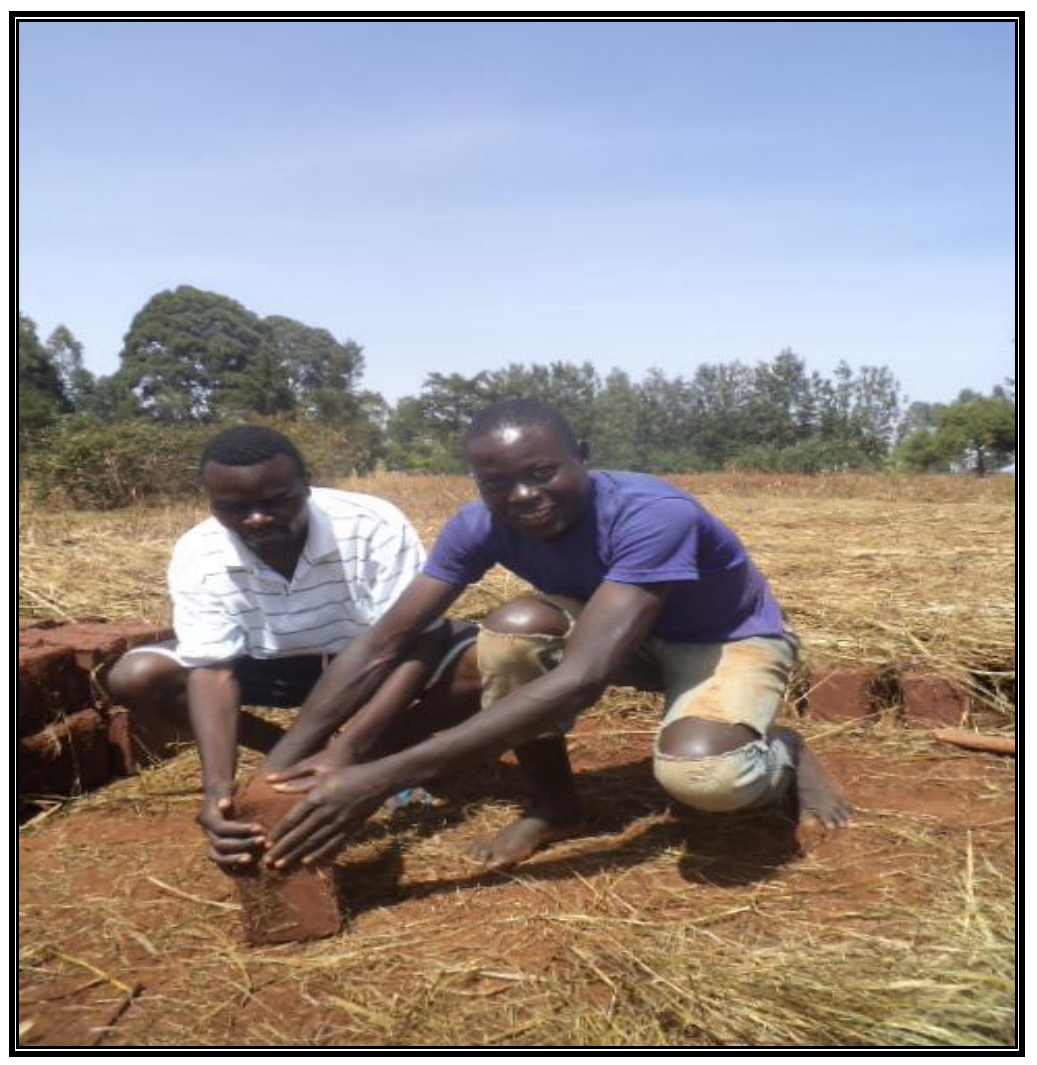

2014, Vol. 4, No. 4

Plate 3: The researcher (left) posing for a picture at a brick-making site in Kivaywa in December 2012.

\subsubsection{Liquor Production}

Data collected through questionnaires showed that 18 percent of the total number of respondents (226) took part in liquor production. The percentage of those who engaged in liquor production in Manda, Mukhonje, and Kivaywa was 24 percent, 5 percent, and 25 percent. Those who participated in Focus Group Discussions and Key Informant Interviews had identified liquor production as one of the cottage industries in the areas of study. The major raw materials are maize flour and finger millet.

Liquor production cottage industries were either self-owned, family-owned, or owned through partnership. Women were the ones who were actively involved in liquor production. Men assumed passive roles, for instance, that of providing raw materials. The girls helped their mothers with work in the kitchen during production, and in most cases, it was work for no pay. Work for no pay was common in instances whereby the worker was a member of the family, a close friend, a business partner, or a neighbor who owned a liquor production industry.

In regard to the place of liquor and brew in the Luhya community of Western Kenya, a village elder said: "A cultural event is not complete unless it is crowned by the taking of traditional brew and liquor. Brew and liquor were used in a number of ways. For example, in the appeasement of ancestors, a little drink was poured on the ground. Elders also read the behaviour of the shape of the top foam of the brew to interpret matters in the community to do with peace, war, hunger, et cetera". 


\section{Macrothink $\Lambda$ Institute"}

In the preparation of liquor, a big pot is placed on the firestones, and on top of it is put a container with a hollow bottom. Inside it is a smaller container that collects the steam, and atop it is placed a bigger container with cold water for cooling the steam that drops into the small container to form liquor. Brew is easier to make. Fermented finger millet flour is put in a big container with a mixture of water and fermented maize flour, and boiled. The porridge-like substance is then mixed with molasses to sweeten it. In Kenya, liquor production is prohibited by the law. Matzopoulos et al (2011) looked into the economic contribution of liquor. See Plate 4:

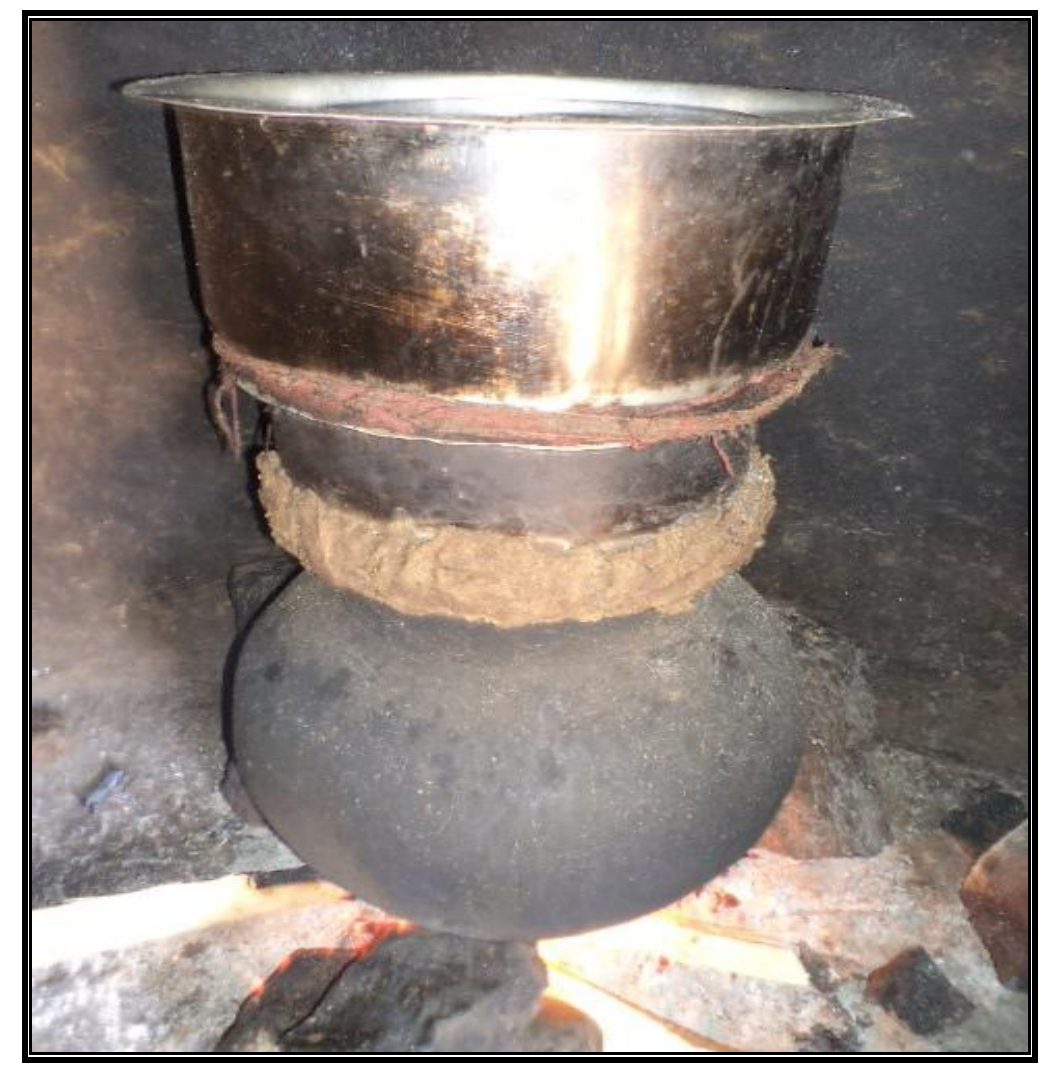

Plate 4: A picture taken in Mukhonje Sub-Location in December 2012, by the researcher, of the set-up for liquor production.

\subsubsection{Quarrying \& Masonry}

Data collected through questionnaires showed that 7 percent of the total number of respondents (226) in this study took part in quarrying and masonry. The percentage of those who engaged in quarrying and masonry in Manda, Mukhonje, and Kivaywa was 12 percent, 5 percent, and 4 percent respectively. Focus Group Discussions and Key Informant Interviews had identified quarrying and masonry as one of the cottage industries in the areas of study. The masonry-based cottage industries were either self-owned or family-owned. Work for no pay was in cases whereby the worker was a member of the family, close friend, business partner, or a neighbor who owned a quarrying or masonry industry.

On the uses of stones and rocks, a village elder said: "Stones were mostly used in the traditional African communities to erect perimeter walls around villages to keep off wild 


\section{Macrothink Institute ${ }^{\mathrm{TM}}$}

animals and also shield the homesteads from ambushes from hostile communities. Statues of iconic leaders were curved from soft rocks. As years go by, more people begun using stones for construction, and slowly shift from mud-walled houses".

Masons in the areas of study earned money from their quarrying activities, and as a result, were able to meet the needs of their families and even invest in other business ventures. Customers came from nearby towns with trucks to buy and carry away the stones and ballast. Birabwa (2006) looked into the ways in which quarrying transformed the socio-economic lives of those who engaged in it. See Plate 5.

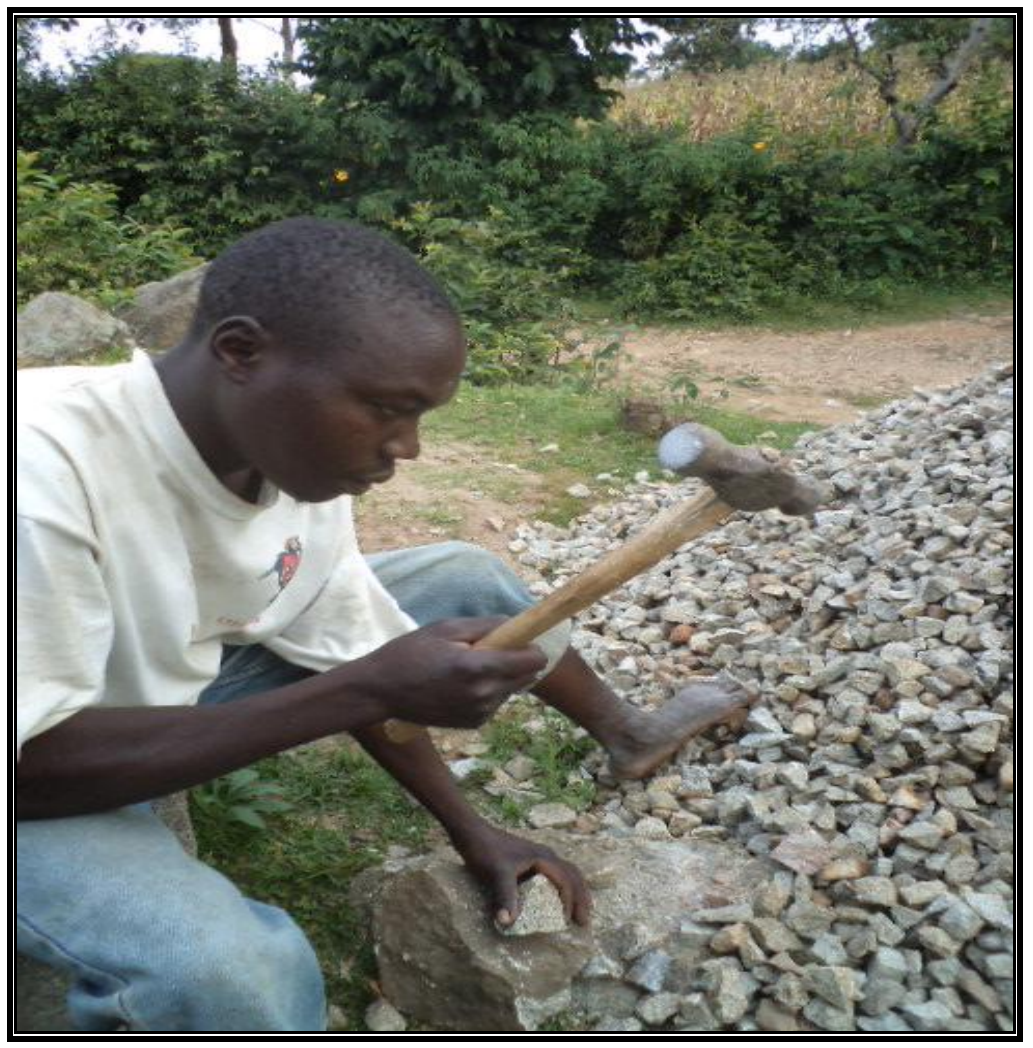

Plate 5: A picture taken in Mukhonje Sub-Location in December 2012, by the researcher, of a young man splitting a rock with the use of a hammer.

\subsubsection{Tree Logging \& Carpentry}

Data collected through questionnaires indicated that 11 percent of the total number of respondents (226) in this study participated in tree logging and carpentry. The percentage of those who took part in carpentry in Manda, Mukhonje, and Kivaywa was 13 percent, 7 percent, and 12 percent respectively. Those who took part in the Focus Group Discussions and Key Informant Interviews had cited carpentry as one of the cottage industries in the areas of study. Timber is the main raw material.

Carpentry-based cottage industries were either self-owned, family-owned, or owned through partnership. Work for no pay was in cases where by the worker was a member of the family, close friend, or a neighbor who owned the carpentry-based industry. All the carpenters in the areas of study were male.

On the uses of trees, a village elder said: "Trees were highly valued in the African traditional 
society. This explains why forests were better conserved in the traditional African settings. Trees would be used for medicinal purposes, improvising foot bridges, making simple furniture, and curving weapons. Long time ago, only axes were used in felling trees, but nowadays, handsaws, power saws, and other sophisticated equipments are used in tree logging and carpentry".

Most of the carpenters had stores for keeping their finished products. The little income derived from the sale of their furniture enabled them to meet their day-to-day needs. Examples of timber products included: chairs, tables, beds, cupboards, and stools. King (1996) looked into the different kinds of trade, including carpentry. See Plate 6.

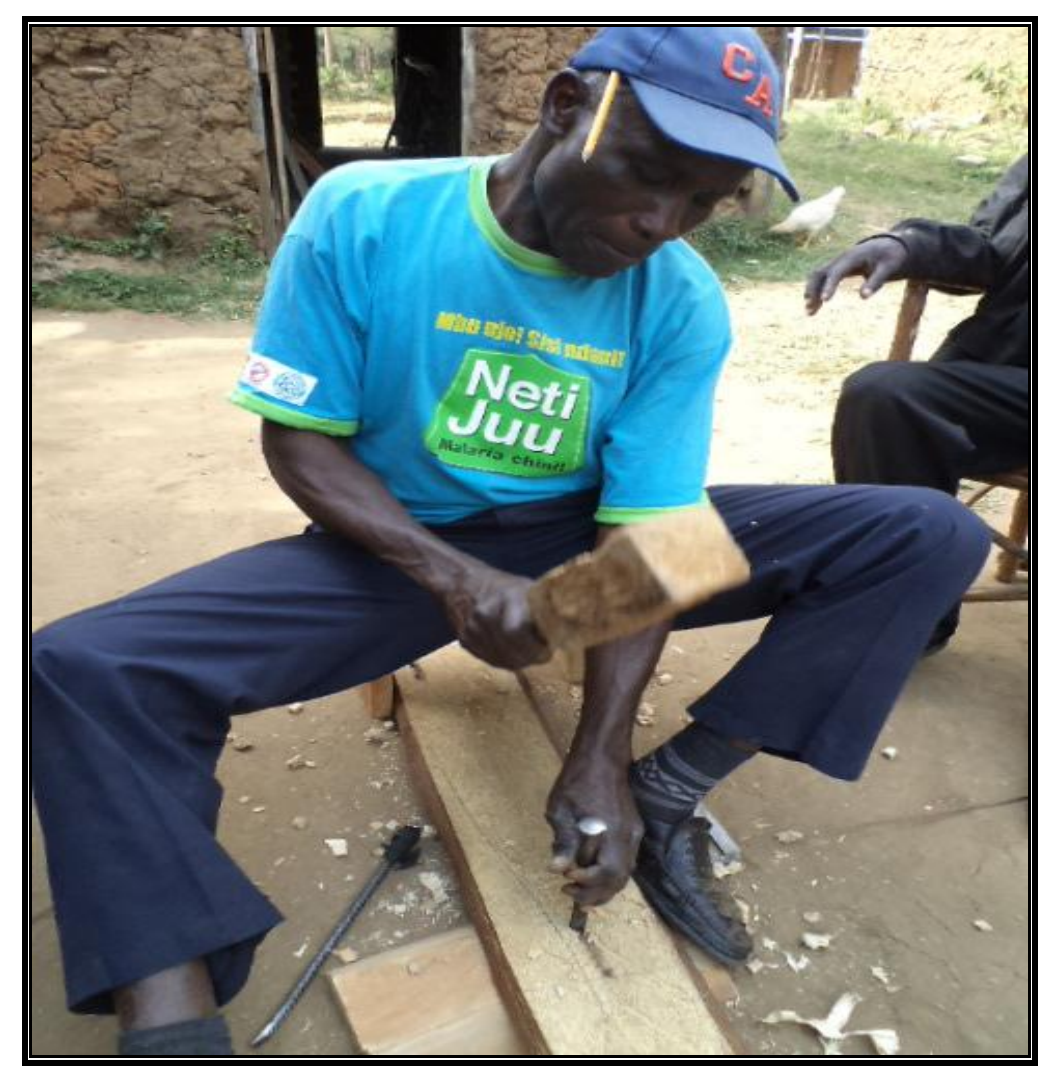

Plate 6: A picture taken in Manda Sub-Location in December 2012, by the researcher, of a carpenter using a mallet and a chisel on a piece of wood.

\subsubsection{Traditional Medicine Extraction}

Data collected through questionnaires showed that 3 percent of the total number of respondents (226) in this study took part in the extraction of traditional medicine. The percentage of those who engaged in traditional medicine extraction in Mukhonje and Kivaywa was 4 percent and 5 percent respectively. Participants in the Focus Group Discussions and Key Informant Interviews in Mukhonje and Kivaywa had cited traditional medicine extraction as one of the cottage industries in the areas. Herbs and roots are the major raw materials.

Traditional medicine-related activities were strictly family-owned since the elderly herbalists passed on the knowledge and skills to their offspring. 


\section{Macrothink Institute ${ }^{\mathrm{TM}}$}

On traditional medicine, a village elder said: "Traditional healing has an important place in the African way of life. There used to be no modern-day pharmaceutical industries, and so, traditional medicine persons were the physicians of the time, and still are. The herbalists walk through bushes and forests in search of herbs with medicinal value. At times they are guided by specific birds and snakes; these snakes and birds spend most of their time around herbs or trees with a specific scent.". Lambert et al (2011) highlighted the contribution of traditional herbal medicine practitioners to Kenyan health-care delivery. See Plate 7:

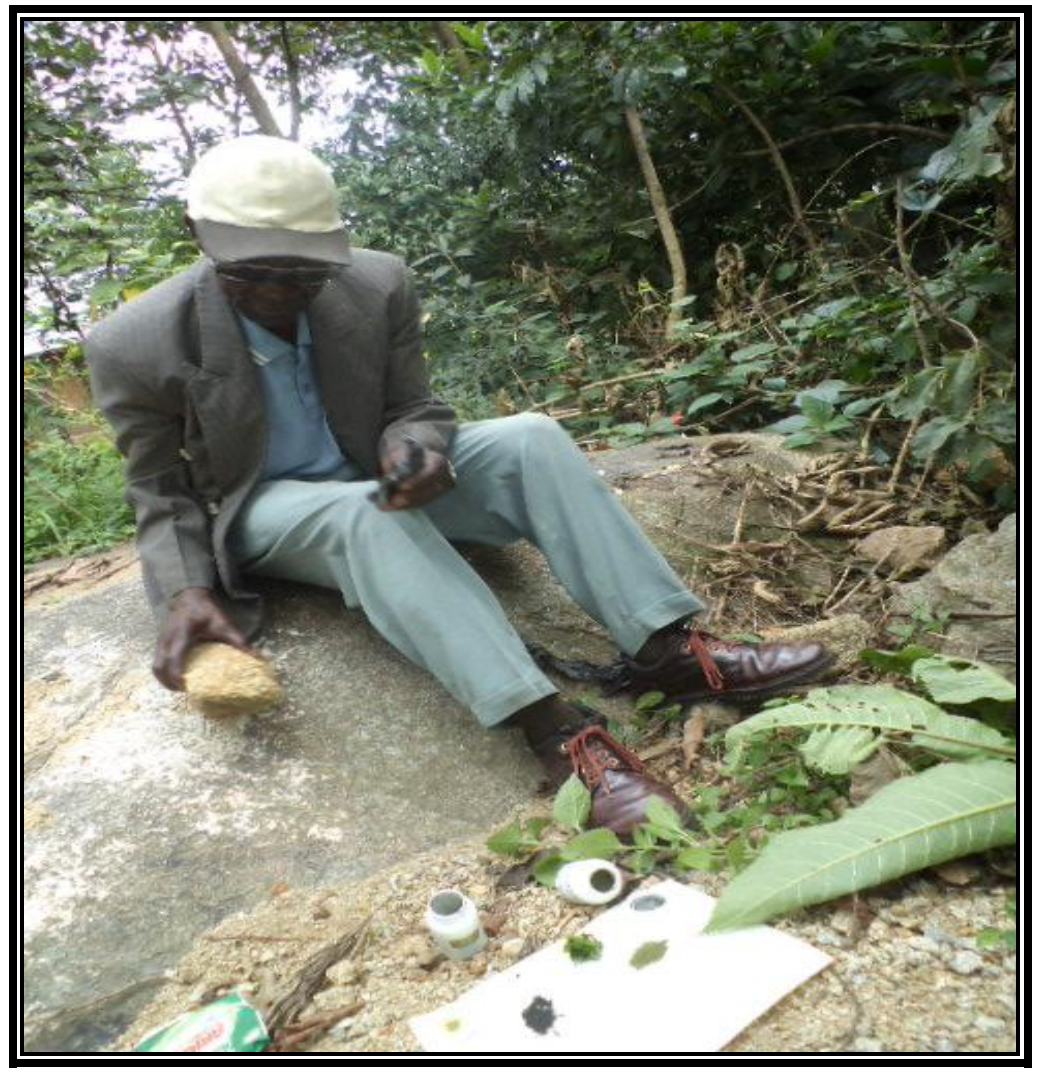

Plate 7: A picture taken in Mukhonje in December 2012 by the researcher, showing a traditional medicine man crushing and drying herbs.

\subsubsection{Charcoal Production}

Data collected through questionnaires showed that 3 percent of the total number of respondents (226) engaged in charcoal production. The percentage of those who engaged in charcoal production in Manda and Mukhonje was 7 percent and 1 percent. The Focus Group Discussions and Key Informant Interviews cited charcoal production as one of the cottage industries in the two areas. Trees are the major raw materials. Charcoal production as a cottage industry was either self-owned, family-owned, or owned through partnership.

As regards the uses of charcoal, a village elder said: "Charcoal burning is a recent activity. It came about after the introduction of clay and metallic stoves or jikos. In the ancient days, Africans exclusively used firewood for cooking. Charcoal was used, in a few cases, for warming the places of residence, especially during cold weather. Nowadays, many people, both in rural and urban areas, use charcoal for cooking of food".

The process involved is simple. Logs of trees are arranged and then covered with soil lumps. 


\section{Macrothink Institute ${ }^{\mathrm{TM}}$}

An opening is left facing the direction in which wind is blowing from. Fire is lit through this opening, and after the logs have begun burning, the opening is sealed so as to limit the amount of oxygen getting in. After around three days, the charcoal is extracted, and is ready for sale or use at the household level. Charcoal dealers from distant markets come with trucks to buy the charcoal and re-sell it at higher profit margins. Ruuska (2012) examined the importance of charcoal production to household income. See Plate 8:

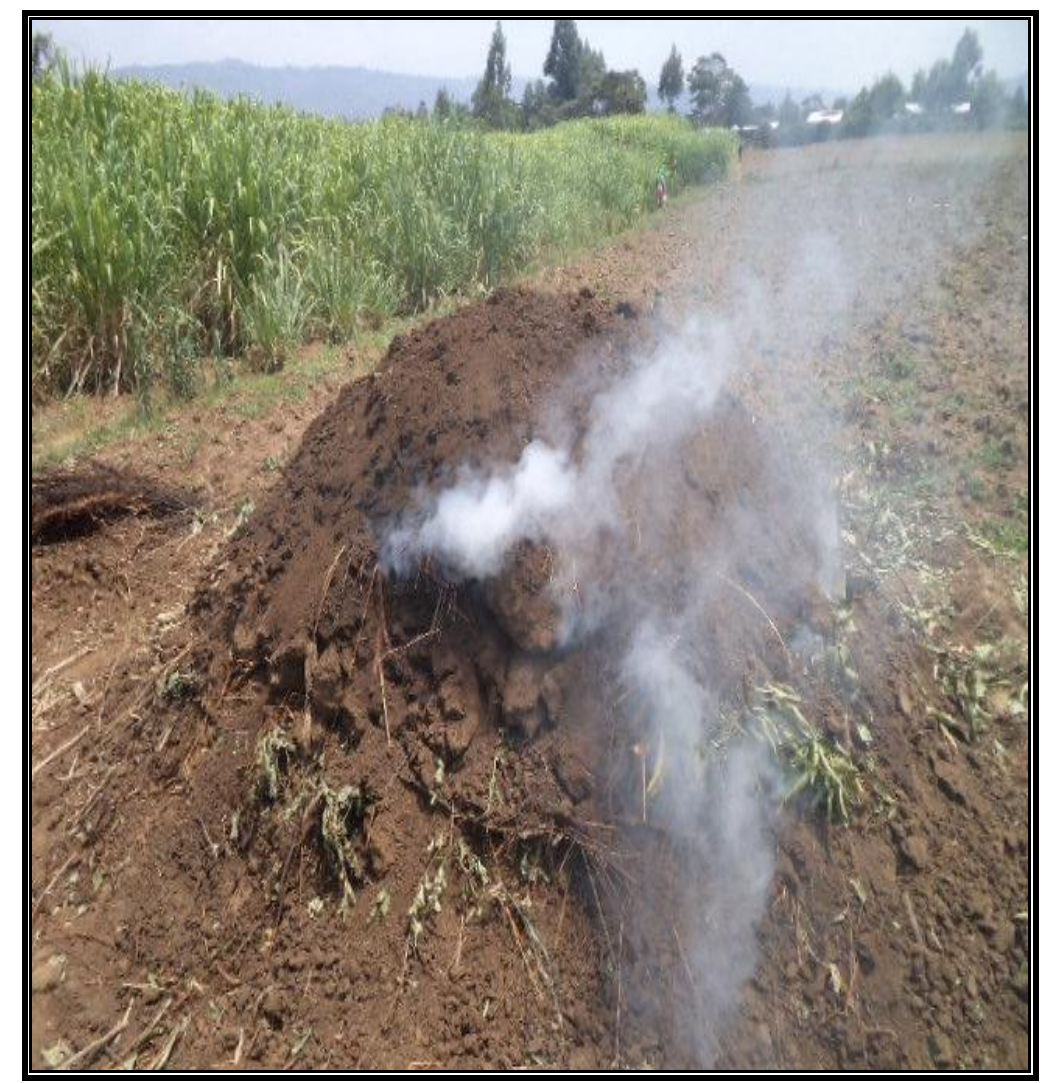

Plate 8: A picture taken in Manda in December 2012 by the researcher, showing a charcoal-burning site.

\subsubsection{Basketry \& Weaving}

Data collected through questionnaires showed that 7 percent of the total number of respondents (226) in this study took part in basketry and weaving. The percentage of those who engaged in basketry and weaving in Manda and Kivaywa was 9 percent and 1 percent respectively. The Focus Group Discussions and Key Informant Interviews identified basketry and weaving as one of the cottage industries in the two areas. Papyrus reeds and the barks of herbs are the major raw materials. Weaving and basketry-based cottage industries were self-owned, family-owned, or owned through partnership. The children would help out their parents or grandparents for no pay.

On the uses of baskets and ropes, a village elder said: "Whenever there is a wedding ceremony, one of the traditional gifts a newly-wed couple is given are baskets, which symbolize abundance, blessings, or productivity. Other uses of baskets include: carrying farm produce, storing grains, covering chicks to prevent predators from carrying them away, use 
in the marketplace, et cetera. Ropes are mostly used for tethering animals".

Ropes are made from sisal. Most people in Western Kenya use sisal plants as landmarks on boundaries. This makes it readily available in most areas. King (1996) looked into the different kinds of trade, including carpentry. See Plate 9.

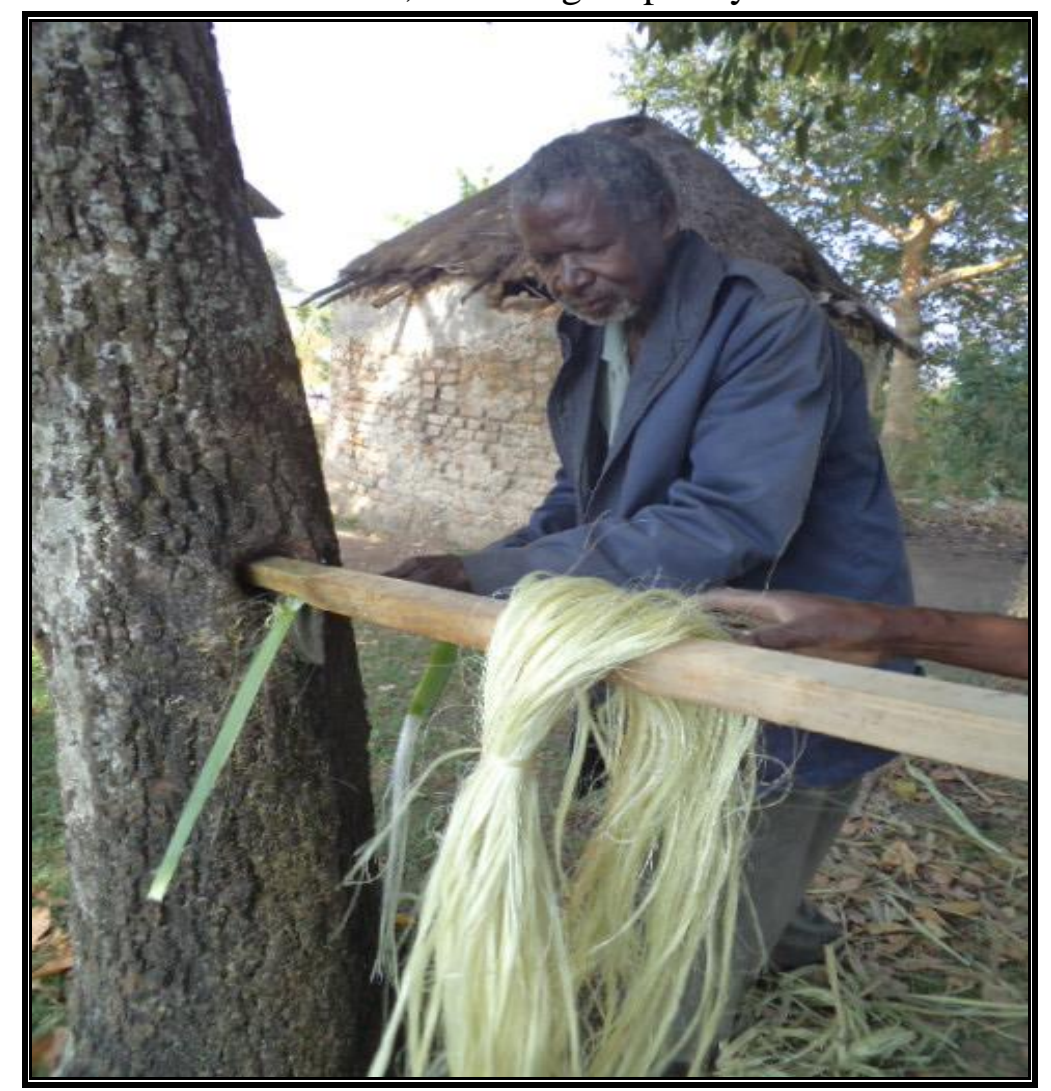

Plate 9: A picture taken in Kivaywa Sub-Location in December 2012, by the researcher, of a man extracting sisal for weaving baskets and ropes.

\subsubsection{Baking}

Data collected through questionnaires indicated that 1 percent of the total number of respondents (226) in this study engaged in baking. The percentage of those who engaged in baking in Mukhonje was 4 percent. The participants in Focus Group Discussions and Key Informant Interviews had identified baking as one of the cottage industries in Mukhonje. Wheat flour is the major raw material.

Bakery-based cottage industries were self-owned, family-owned, or owned through partnership. Baking is a more recent activity. A local leader said: "Baking is a new way of cooking. This is because in the African traditional, the most common way of cooking food was through boiling, roasting and steaming".

Wheat flour is mixed with warm water, sugar, baking powder, oil, and then the kneaded flour is left to stay for a few hours (fermentation) before it is baked into a cake. Bans are easier to make. Pieces of kneaded flour are dipped into heated cooking fat or oil, and when the bans are ready, they are removed from the hot fat. The cakes and bans are now ready for consumption or sale. Rono (2014) looked into baking, though he majored on the adaptation of processing technologies in the bakery industry in Kenya. See Plate 10. 


\section{Macrothink

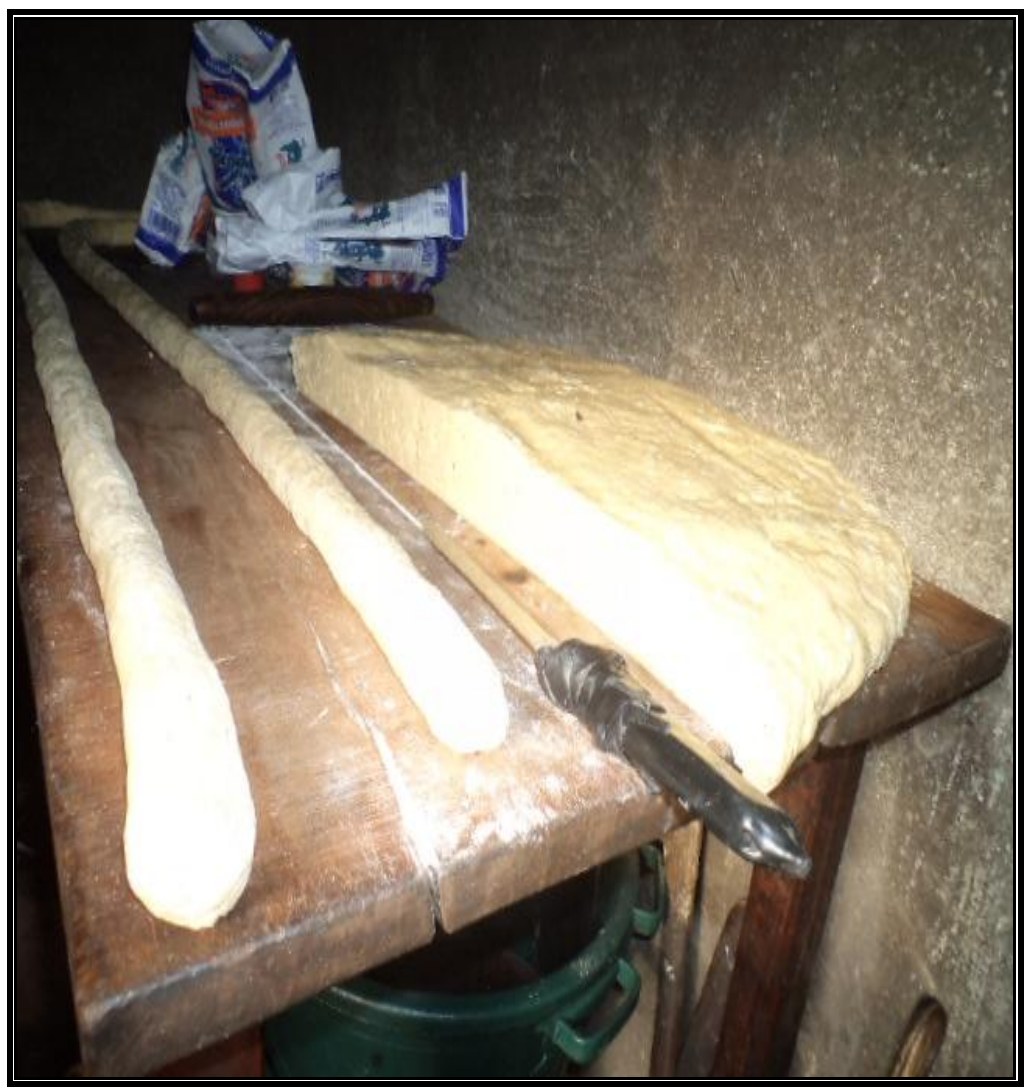

Plate 10: A picture taken in Mukhonje Sub-Location in December 2012, by the researcher, of dough that was to be used in baking.

\subsubsection{Bicycle Repair}

Data collected through questionnaires showed that 2 percent of the total number of respondents (226) in this study engaged in baking. The percentage of those who engaged in bicycle repair in Manda, Mukhonje, and Kivaywa was 3 percent, 1 percent, and 1 percent respectively. The participants in the Focus Group Discussions and Key Informant Interviews identified bicycle repair as one of the cottage industries in the areas.

Bicycle repair cottage industries were self-owned, family-owned, or owned through partnership. The boys who assisted their dad in repairing bicycles worked for no pay. However, the proceeds derived from the work benefitted the whole family. As regards the emergence of bicycles in Kenya, a village elder said: "In the African traditional society, bicycles were rare and were only used by prominent people, for example, Paramount Chief Nabongo Mumia of Wanga, who was gifted a bicycle by the British colonialists. In post-independence Kenya, bicycles have been and still are a common means of transport. They undergo wear and tear, and therefore, break down from time to time. This is when the services of a bicycle repairer are needed. Many people make a living from the repair of bicycles".

This cottage industry was exclusively owned and operated by men. Some of the tools and spare parts used are improvised ones. King (1996) looked into different kinds of trade, including bicycle repair. See Plate 11: 


\section{Ml Macrothink}

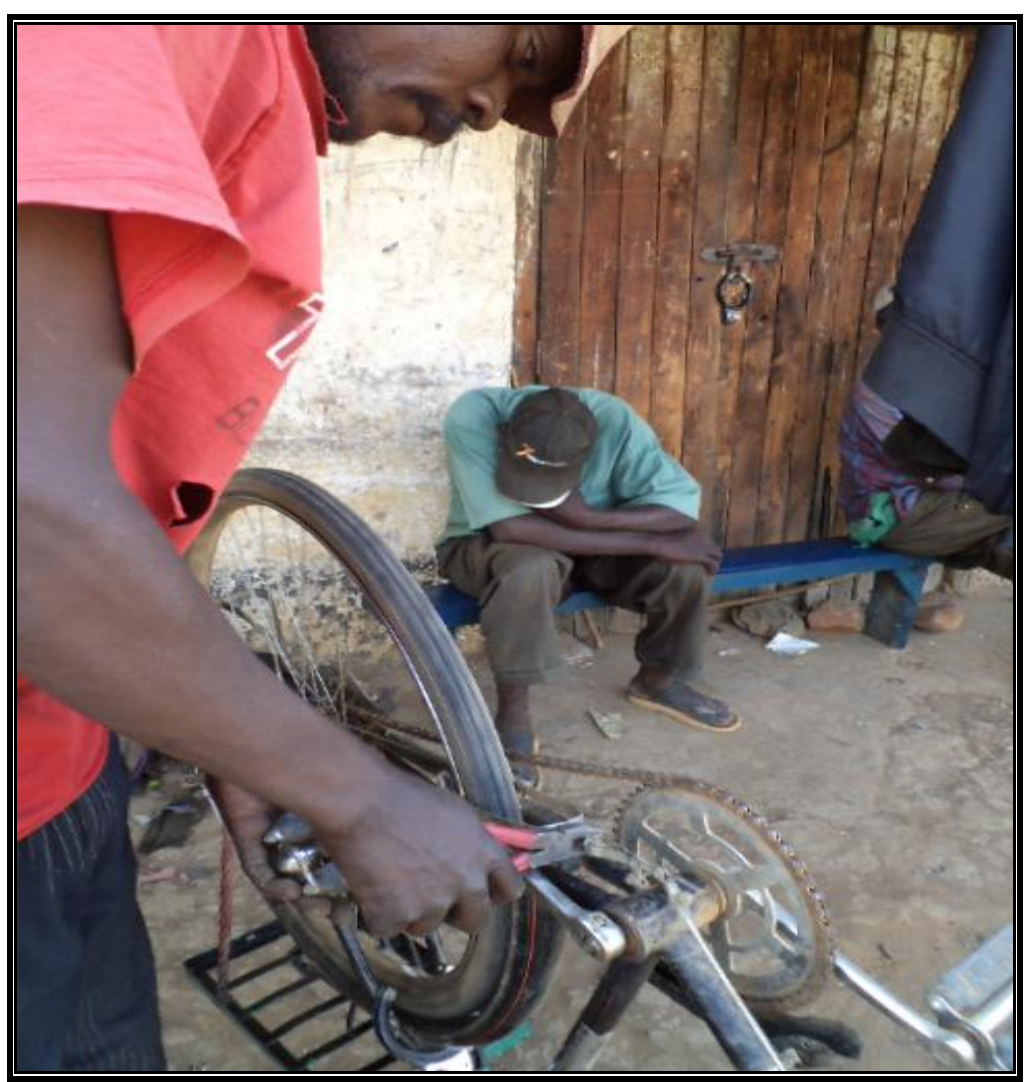

2014, Vol. 4, No. 4

Plate 11: A picture taken in Manda in December 2012, by the researcher, of a man repairing a client's bicycle.

\subsubsection{Flour-grinding}

Data collected through questionnaires showed that 1 percent of the total number of respondents (226) in this study engaged in flour-grinding. The percentage of those who engaged in flour-grinding in Mukhonje was 1 percent. Flour-grinding cottage industry was strictly family-owned. A village elder said: "Diesel-powered mills only came into existence a few decades ago; the people of the past used to grind maize with the use of stones". Flour-grinding entailed the use of two stones to grind cereals. A small stone is used to grind the cereals on the surface of the big stone as the flour is pushed into a basket. Customers paid for the service through barter trade by coming with extra cereals in a small basket which was given to the owner. See Plate 12: 


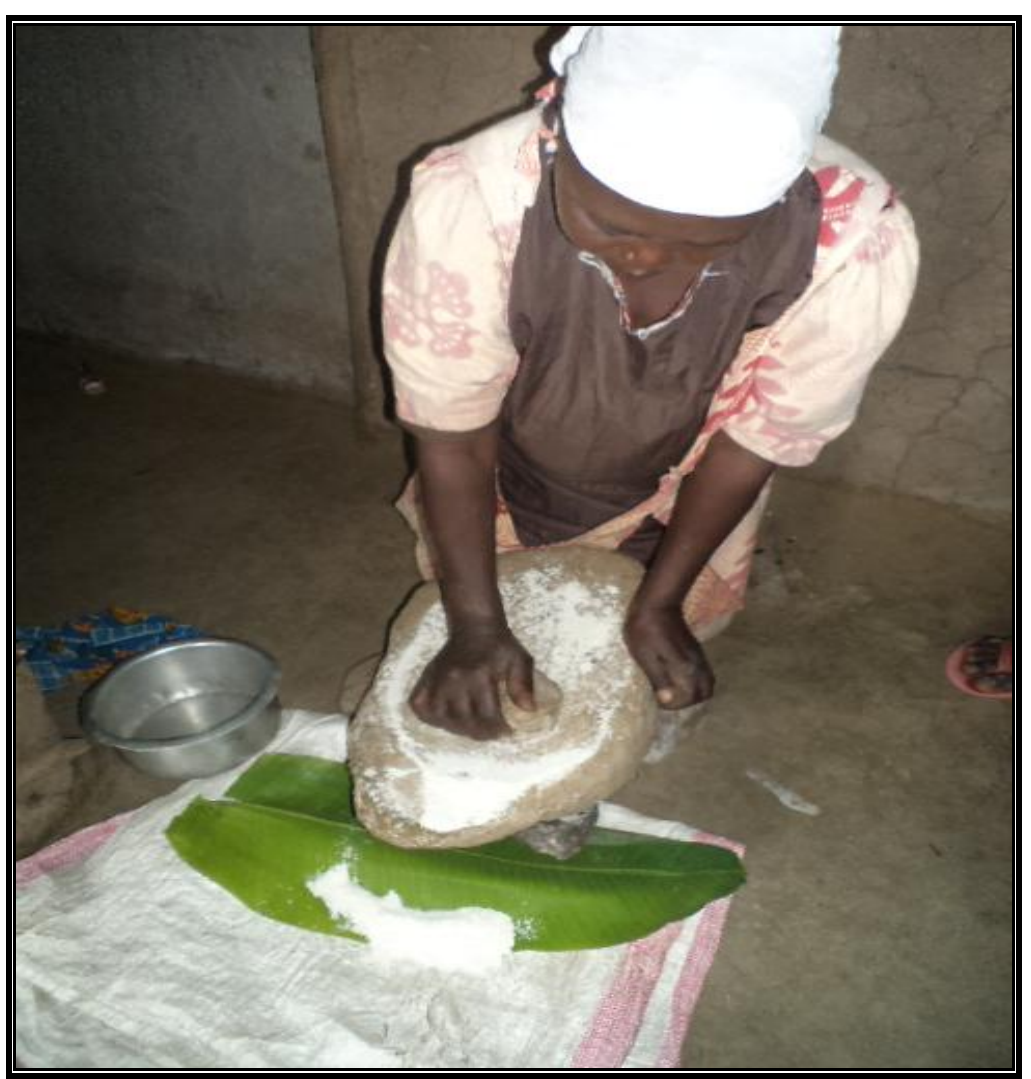

Plate 12: A picture taken in Mukhonje Sub-Location in December 2012, by the researcher, of a woman grinding maize using the traditional grinder.

\subsubsection{Shoe-making \& Repair}

Data collected through questionnaires showed that 1 percent of the total number of respondents (226) in this study engaged in shoe-making and repair. The percentage of those who engaged in shoe-making and repair in Manda and Mukhonje was 2 percent and 1 percent respectively. Hides and skins are the major raw materials. These cottage industries were self-owned, family-owned, or owned through partnership. As regards shoe repair, a village elder said: "In this modern society, since there is no formal company that repairs shoes, shoe repair has become a business niche for some. Others make shoes manually”. King (1996) looked into different kinds of trade, including shoe-making and repair. See Plate 13. 


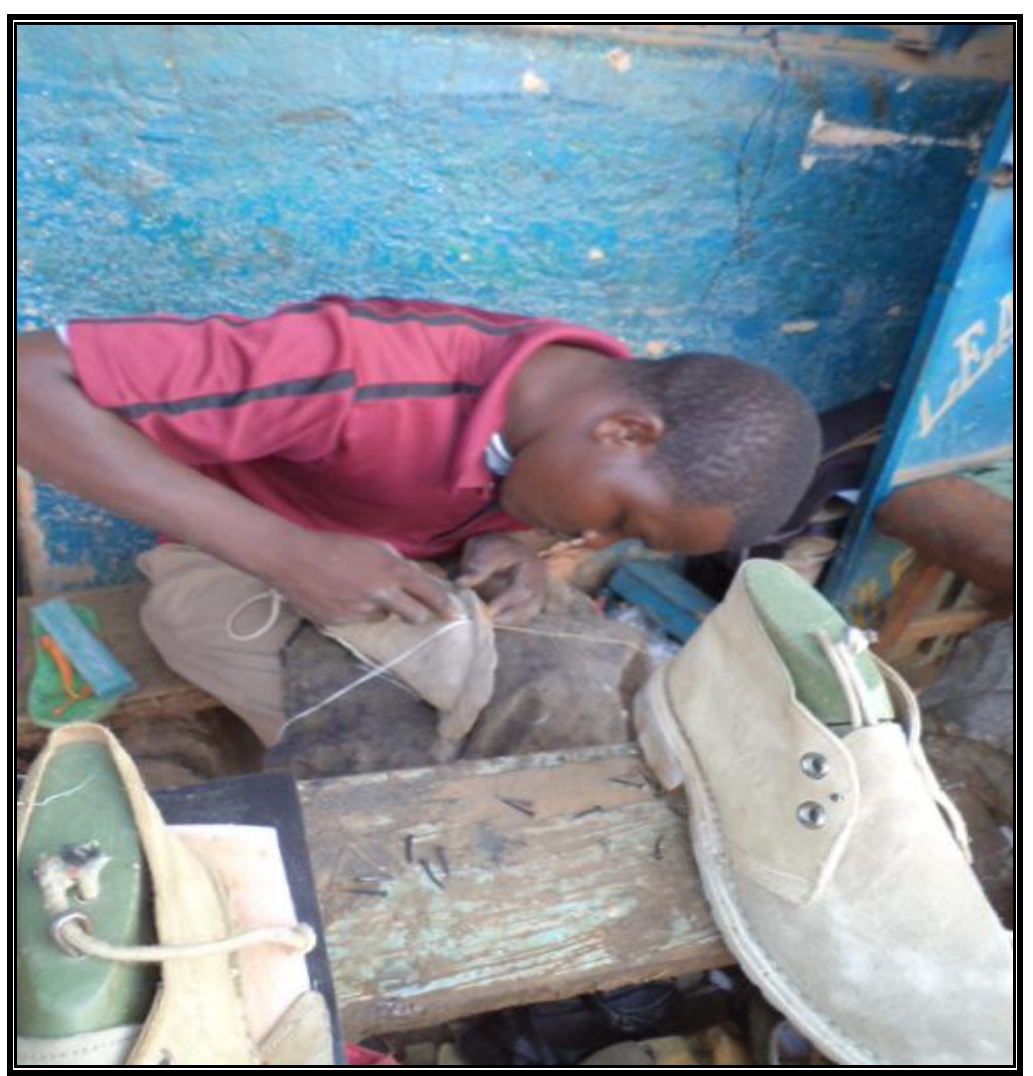

Plate 13: A picture taken in Manda Sub-Location in December 2012, by the researcher, of shoe-makers/repairers busy at work.

Table 2: A summary of the types of cottage industries in Kakamega County

\begin{tabular}{|l|l|l|}
\hline Type of Industry & Frequency & Percent \\
\hline Pottery & 49 & 22 \\
Crude Sugar Production & 18 & 8 \\
Brick-making & 37 & 16 \\
Liquor Production & 41 & 18 \\
Quarrying \& Masonry & 16 & 7 \\
Logging \& Carpentry & 24 & 11 \\
Traditional Medicine & 7 & 3 \\
Charcoal Production & 6 & 3 \\
Basketry \& Weaving & 15 & 7 \\
Bakery & 3 & 1 \\
Bicycle Repair & 4 & 2 \\
Flour-grinding & 2 & 1 \\
Shoe-making \& Repair & 3 & 1 \\
Total & 226 & 100 \\
\hline
\end{tabular}




\subsection{Characteristics of Cottage Industries in Kakamega County}

\subsubsection{Reason for Location of the Cottage Industry}

The reasons for the location of cottage industries were looked into. They were categorized into: access to raw materials, security, cost-saving measure, and other reasons. This question was answered by the owners of cottage industries. This is presented in Figure 6:

Figure 6: The Reason for Location of the Cottage Industry

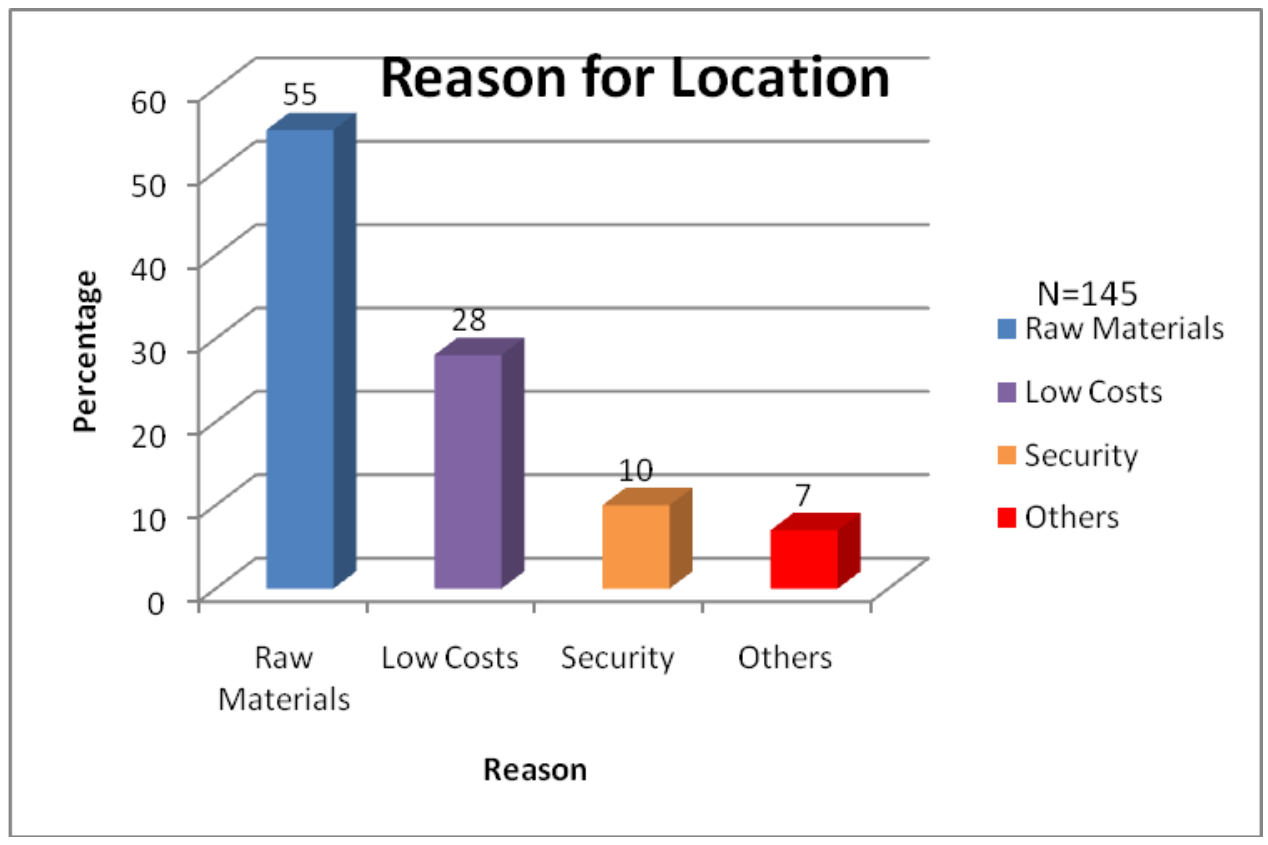

Most of the cottage industries in this study were in the same neighbourhood, and were located close to each other. The Sub-Chief of Mukhonje Sub-Location said: "Our river banks have a lot of clay soil. Therefore, most people in this area own pottery clay-related cottage industries. It is not easy to walk into a home that is not engaging in pottery. Most people prefer having their industries in their homes so as to forego the cost of renting a premise, while others, it is for security reasons".

Huayou (1967) observed that firms in similar or related industries tended to co-locate in particular places (agglomeration theory). Sivaraman et al (1981), in a report on village and cottage industries, concluded that the location and pattern of village and cottage industries have primarily been guided by the exploitation of raw material resources available in the rural areas, and the catering for the basic needs of the people residing there.

\subsubsection{Mode of Ownership}

The three categories of ownership of cottage industries in the areas of study were: self-owned, family-owned, and ownership through partnership. This question was answered by the owners of cottage industries and the responses were summarized in Table 3:

Table 3: The Mode of Ownership of the Cottage Industries 


\begin{tabular}{|l|l|l|}
\hline Mode of Ownership & Frequency & Percent \\
\hline Self-owned & 59 & 41 \\
\hline Family-owned & 82 & 56 \\
\hline Partnership & 4 & 3 \\
\hline Total & 145 & 100 \\
\hline
\end{tabular}

Out of the 226 respondents, 145 were owners of cottage industries. Of the owners, 56 percent had industries that were family-owned and comprised members of a family sharing roles. Those who were sole owners and operators of their cottage industries were 41 percent. All the tasks involved could be carried out by the same person. Those whose ownership was through partnership were 3 percent. Here a group of people interested in a specific cottage industry, both family- and non-family members, would come together and work in the same industry as a team.

Puri (1998) noted that cottage industries provide the greatest opportunity for making every home a factory; this is the concept behind home-based industries; members of the family in a home got involved and benefitted from their involvement in the cottage industry. Self-owned, family-owned, and industries owned through partnership were all located in homes. Johansson et al (2013) categorized mode of ownership into owner and family-owned. In a study in India, Ziolkowski (1996) pointed out that individual proprietorship was the most common form of organization (ownership) of industrial units; he had categorized them into: individual proprietorship, family-owned and partnership.

\subsubsection{Duration of Ownership}

The duration of ownership of a cottage industry was classified into three; period less than a year, period between one and three years, and period more than three years. This question was answered by the owners of cottage industries. This is presented in Figure 7.

Figure 7: The Duration of Ownership of the Cottage Industries 


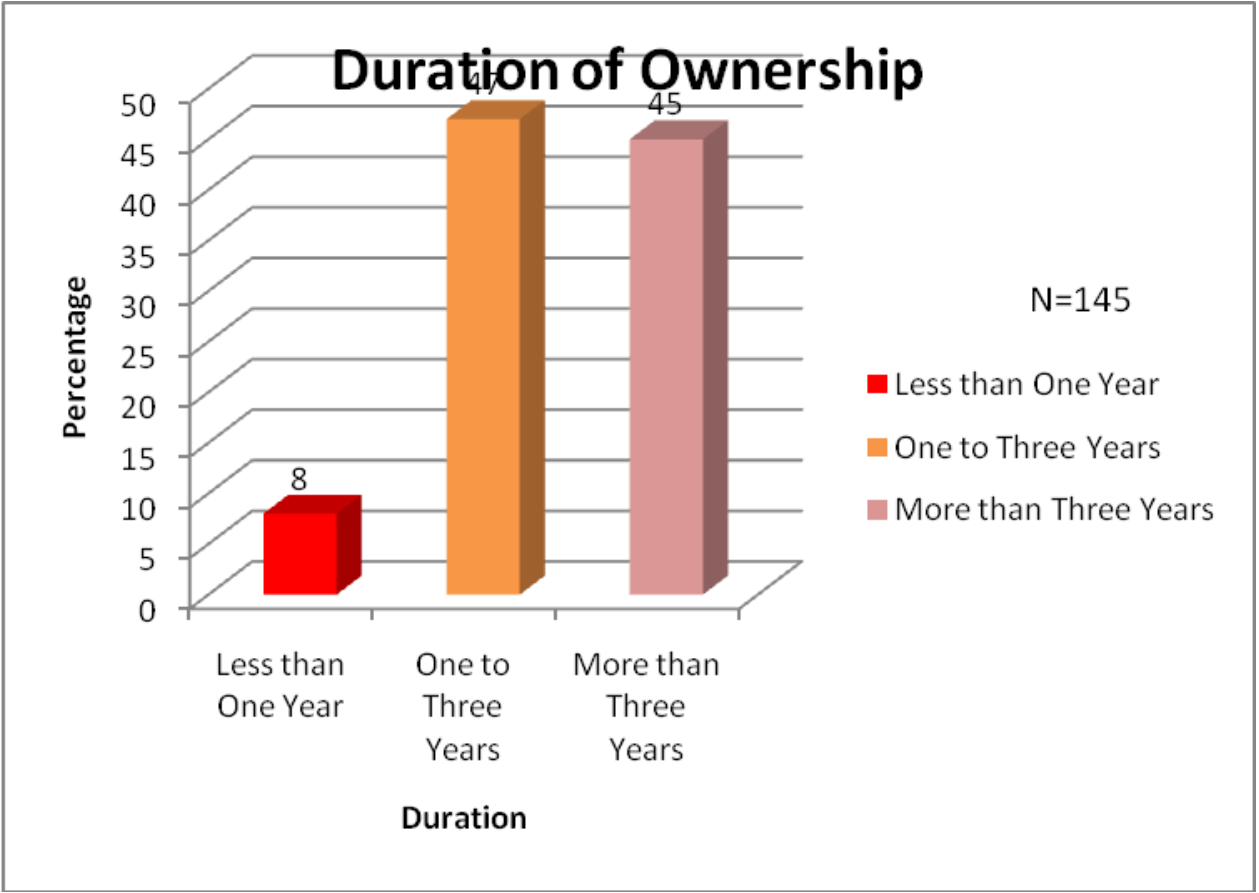

Data in Table 8 shows that those who had owned a cottage industry for a period of less than a year were 8 percent while those who owned it for a period of more than three years were 45 percent. It is worth noting that those who had owned a cottage industry for more than three years were almost half of the respondents (45\%).

Alam et al (2011), while looking into the effect of entrepreneur and firm characteristics on the success of Small and Medium Enterprises in Bangladesh, observed that those enterprises which are operated for a longer duration have been more successful in comparison to the ones that have been in operation for a shorter duration.

\subsubsection{Duration of Employment}

This question was directed to workers in the cottage industries. The duration of employment was classified into three; period less than a year, period between one and three years, and period more than three years. This is summarized in Figure 8.

Figure 8: The Duration of Employment in the Cottage Industries 


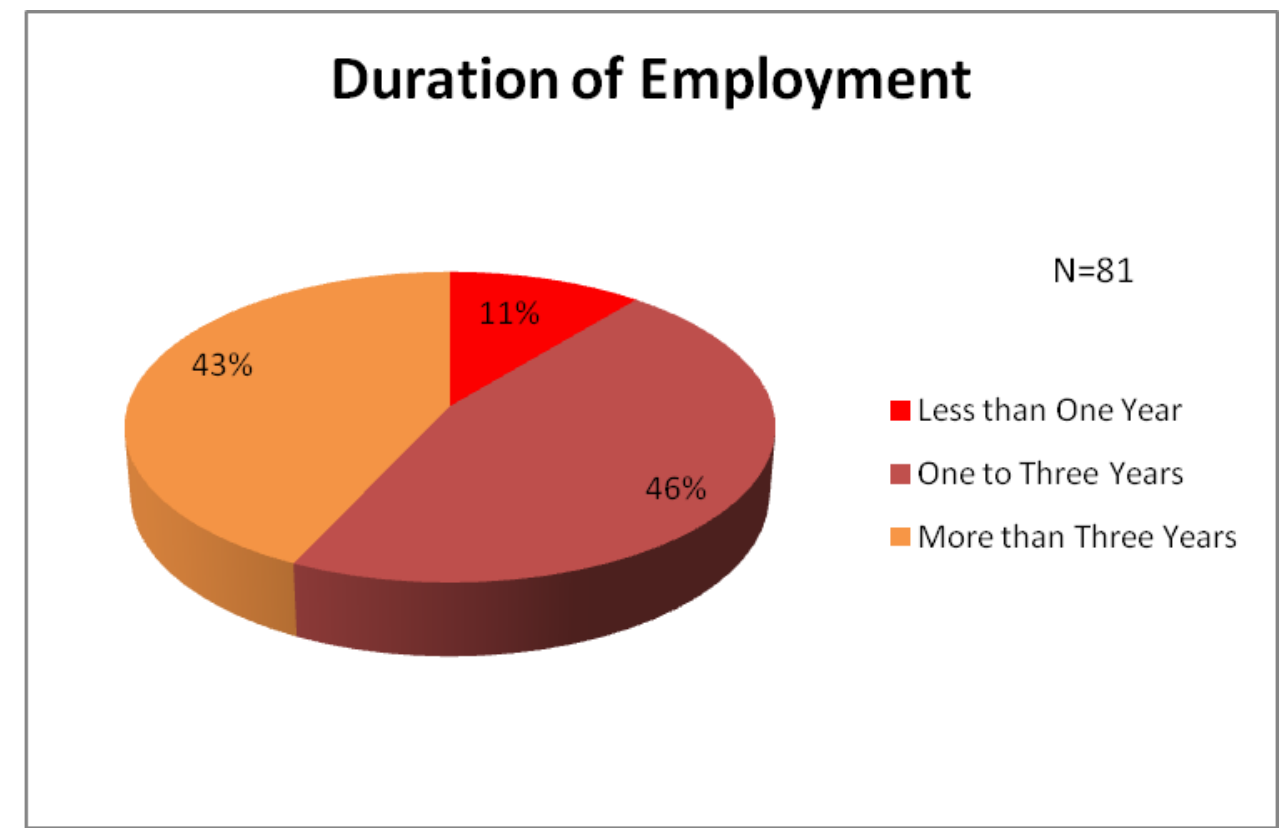

Data in Figure 8 shows that those who had been employed in a cottage industry for less than a year were 11 percent while those who had been employed beyond three years were 43 percent. It is worth noting that those who had worked in a cottage industry for more than three years were almost half of the total number of workers. Alam et al (2011) noted that the length of time in operation may be associated with a learning curve; old owners and workers in the Small and Medium Enterprises most probably have learned much from their experience than newcomers.

\subsubsection{State of the Cottage Industry}

This section highlights the present state of the industry; if it is fully functional or not fully functional. This question was directed to both owners and workers in cottage industries. This is summarized in Figure 9.

Figure 9: The State of the Cottage Industries

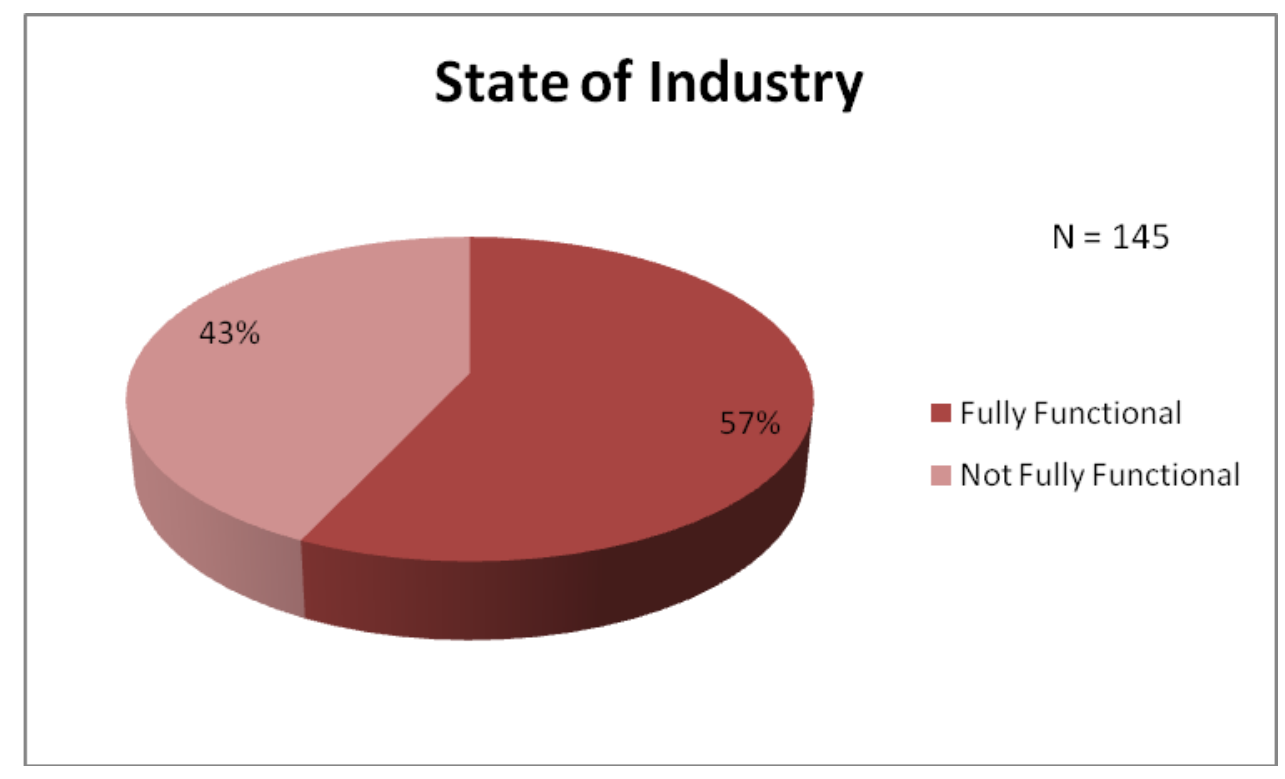


Those who thought the cottage industries they owned or operated in were fully functional were 57 percent whereas those who thought the industries they owned or operated in were partially functional were 43 percent. Slightly more than half of the cottage industries were, despite the numerous challenges, fully functional.

\subsubsection{Nature of Employment}

The nature of employment was categorized into: all-year employment and seasonal employment. This is presented in Figure 10.

Figure 10: The Nature of Employment in the Cottage Industries

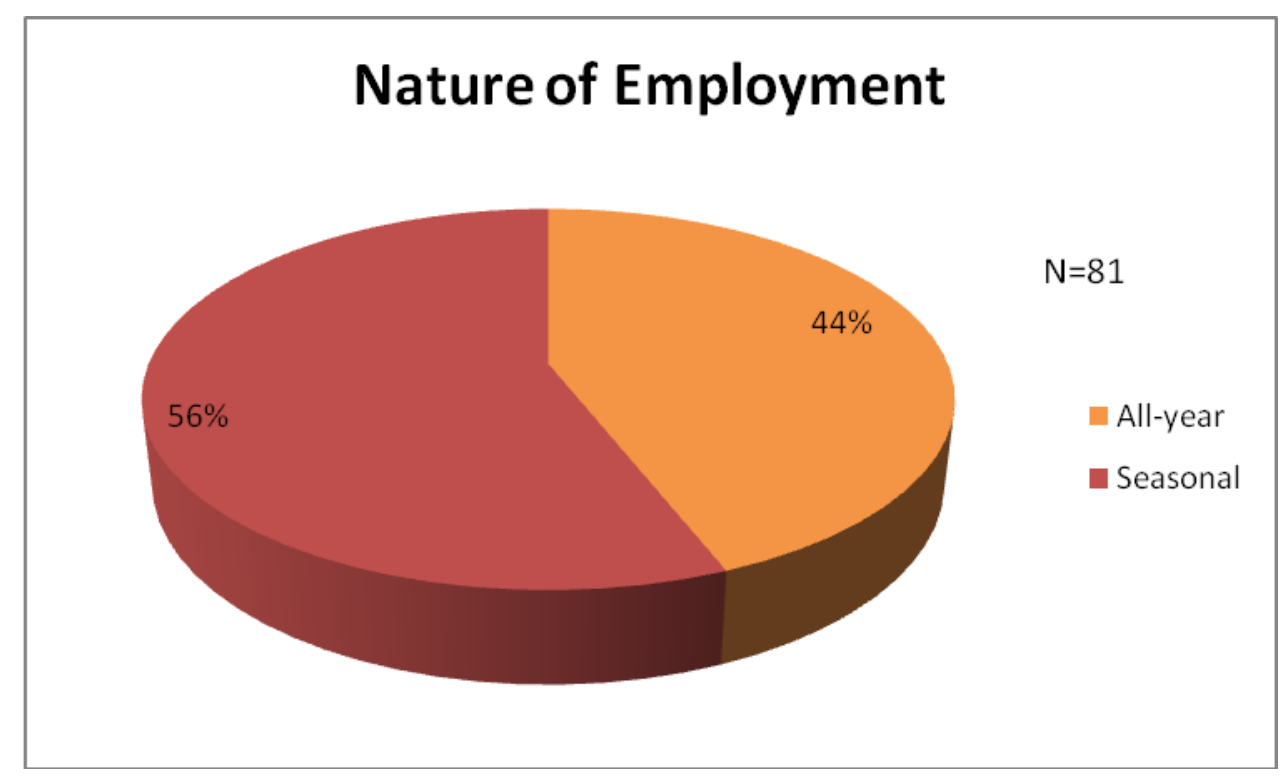

This question was asked with the aim of establishing the seasonality or permanency of the employment opportunities offered by cottage industries. Those who were in employment throughout the year were 45 percent whereas those whose work was seasonal were 55 percent. Slightly more than half of the cottage industries were dependent on raw materials which were mostly available after the harvesting season. Also, during the planting season, a good number of the owners and operators of the cottage industries would reduce their involvement in the industries and focus more on farming.

The seasonality of some activities of cottage industries is another challenge. This is because the operations were highly seasonal in most of the industries. Staley and Morse (1965) pointed out that a good majority of the owners pursued subsidiary avocations mainly as farmers or agricultural laborers. Rao and Saha (1986) also observed that the development of cottage industries provided part-time occupation to the people engaged in agriculture and full-time jobs to the village artisans and craftsmen.

\subsubsection{Type of Employment}

This section highlights the type of employment offered by these cottage industries, that is, whether it is permanent-based, casual-based, or contract-based. This is summarized in Table 
4.

Table 4: The Type of Employment in the Cottage Industries

\begin{tabular}{|l|l|l|}
\hline Type of Employment & Frequency & Percent \\
\hline Permanent & 42 & 52 \\
\hline Contract & 2 & 3 \\
\hline Casual & 37 & 45 \\
\hline Total & 81 & 100 \\
\hline
\end{tabular}

This question was asked so as to establish the type of work agreement, whether written or unwritten, through which the employees of cottage industries had entered into with the owners of cottage industries (employers).

Most of the workers (52\%) were working in the cottage industries on a permanent basis whereby the owners of the industry did not easily replace them, unless they chose to quit out of their own volition. Those on casual employment were 45 percent. They would hardly work for the same person beyond a week. Those working on contract basis were only 3 percent. They had entered into a formal contract that determined the amount of wages they would get for the specified period of time they were working in the given industry. An advocate said: "Most people are not willing to enter into contractual agreements because of the fear of engaging in possible legalities, as opposed to the traditional agreements based on trust".

Rao and Saha (1986) observed that the development of cottage industries can provide part-time occupation to the people engaged in agriculture and full-time jobs to the village artisans and craftsmen.

\subsection{CONCLUSION}

The findings in this study added knowledge to empirical research by highlighting the characteristics of cottage industries. The central government and the county governments should facilitate the documentation of all cottage industries existing in the country. This will help shed light on their contribution to the economy, the impediments they grapple with, and how best to establish them. This recommendation has been made within the scope and limitation of this study

\section{REFERENCES}

Alam et al (2011). "Effect of Entrepreneur and Firm Characteristics on the Success of Small and Medium Enterprises (SMEs) in Bangladesh", in the International Journal of Business and Management: East West University of Bangladesh, Vol. 6, No. 3.

Birabwa, Elizabeth. 2006. Small-scale Stone Quarrying: Its Contribution to People's Livelihoods; A Case Study of Kasenge Parish, Nama Sub-County, Mukono District, Uganda: Department of Geography, Norwegian University of Science and Technology.

Blackden, C. M, and Wodon., Q (Eds). 2006. "Gender, Time Use, and Poverty in Sub-Saharan Africa (World Bank Working Paper No. 73)": World Bank, Washington, D. C.

Faridi, M. Z. 2009. "The Socio-Economic and Demographic Determinants of Women Work Participation in Pakistan: Evidence from Bahawalpur District", in the Research Journal of South Asian Studies, Vol. 24, No. 2 (pp. 351-367). 


\section{MlMacrothink}

International Journal of Human Resource Studies

ISSN 2162-3058

2014, Vol. 4, No. 4

Fourth Kenya Human Development Report: Linking Industrialization with Human Development, (2005; pp. v-viii, 1-3): United Nations Development Programme.

Johansson et al (2013). The Ownership Types Influence on Internationalization Strategy: A Case Study on How and Why Ownership Type Influences Firms' Internationalization Strategy: Linnaeus University, School of Business and Economics.

Kakamega District Development Plan, 1997-2001 (pp. 37-47). Rural Planning Development, Office of the Vice-President and Minister of Planning and National Development, Nairobi, Kenya.

Kaplan., (2009). Kaplan AP European History 2009: Kaplan Publishing Company, New York, United States of America.

Kenya National Bureau of Statistics: 2009 Kenya Population and Housing Census Volume 1A (August, 2010; pp. 27-33 and 179-193)

Kenya National Bureau of Statistics: 2009 Kenya Population and Housing Census Volume 1B (August, 2010; pp. 218)

Krejcie, R. V., and Morgan, D. W., (1970). Determining Sample Size for Research Activities: University of Minnesota and Texas A. and M. University, U.S.A.

Matzopoulos et al (2011). Baseline Study of the Liquor Industry: DNA Economics, South Africa.

Morse, R., and Staley, E (1965). Modern Small Industry for Developing Countries (pp. 4, 36-44): McGraw-Hill Book Company, Australia, Canada, U.K, U.S.A.

Mosaddeque et al (2008). Farmers' Characteristics Associated with the Participation in Cottage Industry Activities of BAUEC. j.innov.strategy. 2(3): 38

Nachmias, C. F., and Nachmias, D., (1996). Research Methods in the Social Sciences (pp. 97). University of Wisconsin, USA: Hodder Headline Group Publishers.

Puri, N. K., (1988). Rural Industrialization in a Modern Economy: A Study of Traditional Wood and Metal Crafts of Alwar (pp. 1-30): National Book Organization.

Rao., and Saha. 1986. Complete Guide to Rural Industrialization (pp. 17-46): Sri Durga Pustak Bhandar Publishers, India.

Rono, H.K., (2014). Adaptation of Processing Technologies in the Bakery Industry in Kenya: McGrill University.

Ruuska E., (2012). The Significance and Sustainability of Charcoal Production in the Changing Landscape of Dakatcha Woodland, SE Kenya (pp. 91). University of Helsinki, Finland.

Sivaraman et al (1981). Report on Village and Cottage Industries: National Committee on the Development of Backward Areas Planning Commission, Government of India.

Ziolkowski, Janusz. 1966. Small Industries and Social Change, UNESCO Research Centre on Social Economic Development in Southern Asia: Allied Publishers Private Ltd. 